\title{
Article
}

\section{The Impact of Terrorism on Governance in African Countries}

\author{
Asongu, Simplice and Nwachukwu, Jacinta Chikaodi \\ Available at http://clok.uclan.ac.uk/25150/ \\ Asongu, Simplice and Nwachukwu, Jacinta Chikaodi ORCID: 0000-0003-2987- \\ 9242 (2017) The Impact of Terrorism on Governance in African Countries. \\ World Development, 99 . pp. 253-270. ISSN 0305-750X
}

It is advisable to refer to the publisher's version if you intend to cite from the work. http://dx.doi.org/10.1016/j.worlddev.2017.05.023

For more information about UCLan's research in this area go to http://www.uclan.ac.uk/researchgroups/ and search for < name of research Group>.

For information about Research generally at UCLan please go to http://www.uclan.ac.uk/research/

All outputs in CLoK are protected by Intellectual Property Rights law, including Copyright law. Copyright, IPR and Moral Rights for the works on this site are retained by the individual authors and/or other copyright owners. Terms and conditions for use of this material are defined in the policies page.

\section{CLoK}

Central Lancashire online Knowledge www.clok.uclan.ac.uk

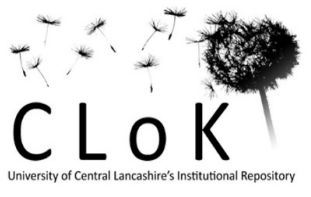




\section{The Impact of Terrorism on Governance in African Countries}

Simplice Asongu and Jacinta C. Nwachukwu

January 2017 


\section{A G D I Working Paper}

\section{WP/17/019}

The Impact of Terrorism on Governance in African Countries

Forthcoming in: World Development

\section{Simplice A. Asongu}

African Governance and Development Institute,

P.O. Box 8413 Yaoundé, Cameroon.

E-mail: asongusimplice@yahoo.com

\section{Jacinta C. Nwachukwu}

School of Economics, Finance and Accounting,

Faculty of Business and Law,

Coventry University Priory Street, Coventry, CV1 5FB, UK.

Email: jacinta.nwachukwu@ coventry.ac.uk 


\title{
Research Department
}

\section{The Impact of Terrorism on Governance in African Countries}

\section{Simplice A. Asongu \& Jacinta C. Nwachukwu}

January 2017

\begin{abstract}
This study investigates how terrorism affects governance in 53 African countries for the period 1998-2012. Four terrorism indicators are used namely: domestic, transnational, unclear and total terrorism. Ten bundled and unbundled governance indicators are also employed namely: political governance (consisting of political stability and voice and accountability), economic governance (encompassing government effectiveness and regulation quality); institutional governance (entailing corruption-control and the rule of law) and general governance. The governance indicators are bundled by means of principal component analysis. The empirical evidence is based on Generalized Method of Moments. Three key findings are established. First, all selected terrorism dynamics negatively affect political governance and its constituents. Second, evidence of a negative relationship is sparingly apparent in economic governance and its components. Third, no proof was confirmed in relation to the impact of terrorism and institutional governance with its elements. Fourth, compared with domestic terrorism, transnational terrorism more negatively and significantly affects political, economic and general governances. Policy implications are discussed.

JEL Classification: C52; D74; F42; O38 ; P37

Keywords: Terrorism; Governance; Africa
\end{abstract}




\section{Introduction}

There are two main reasons motivating this inquiry, namely: (i) growth trends of terrorism in Africa and (ii) gaps in the literature.

First, terrorism is a growing concern in Africa (Alfa-Wali et al., 2015). Whereas terrorism in not entirely new on the continent, the magnitude with which it is increasing is dismal. Today Africa is a fertile environment for the growth of terrorism because of a plethora of characteristics, among others: religious fundamentalism, tribal and ethnic tensions, growing regional and political instability and ideologies of extremists groups that are lobbying to establish new states in replacement of old ones (Fazel, 2013). Whereas the world is currently focusing on the Middle East comparatively, Africa is not being given the scholarly attention it disserves, in spite of growing radicalization and Islamic fundamentalism therein (Clavarino, 2014). Some notable examples of such extremist groups include: al-Qaeda in the Islamic Maghreb, the Boko Haram of Nigeria and al-Shabab in Somalia.

Second, whereas the substantial bulk of the literature has focused on governance as a tool in mitigating terrorism, scholarly focus on the influence of terrorism on governance is limited. Accordingly, the literature on whether good governance promotes or mitigates terrorism has been the subject of much debate in the literature (see Lee, 2013). There is a branch of the literature which argues that some fundamental characteristics in good governance can reduce the likelihood of terrorism (or recruitment by terrorists' organizations) by reducing resentment towards the State (Windsor, 2003; Li, 2005). Conversely, another stream of the literature disputes that good governance is not an important instrument in reducing terrorism because in democratic politics, terrorist interests are represented in the institutions of government (see Gause, 2005). In essence, societies with comparatively better levels of democratic institutions can harbor terrorism because there are a series of features in these societies that are conducive for the growth of terrorism. These consist of among others: civil liberties, freedom and access to media and freedom of speech in the expression of dissatisfaction and disagreement (Ross, 1993). While political access theories (see Eyerman, 1998) argue that the relationship between good governance and terrorism is weak because of features like judicial independence (Findley \& Young, 2011); rule of law (Choi, 2010) and better conditions for conflict management ( $\mathrm{Li}, 2005)$; another stream of the literature argues that terrorism is more likely to develop in conditions of government instability (Lai 2007; Piazza 2008a). The latter perspective is consistent with a broad stream of literature (Schmid, 1992; Eubank \& Weinberg, 1994; Piazza, 2007). 
To be sure, much of the literature has focused on the effect of governance on terrorism. We contribute to the literature by assessing the reverse relationship. It is important to investigate the effect of terrorism on governance because from intuition, terrorism is likely to affect inter alia: (i) political governance or the election and replacement of political leaders; (ii) economic governance or the formulation and implementation of policies that deliver public commodities and (iii) institutional governance or the respect by citizens and the State of institutions that govern interactions between them. Hence, terrorism can substantially affect the role of government in many separate areas, notably improvements in standards of living (Fosu, 2013; Fonchingong, 2014; Anyanwu \& Erhijakpor 2014) and societal change (Fosu, 2015).

The inquiry also contributes to the literature by improving the harmony between the conception and measurement of governance. For instance, whereas political governance is often used in many scholarly circles, the concept is misplaced unless it is justified by some empirical validity. Given that political governance is a combination of 'voice and accountability' and political stability/no violence, a composite indicator encompassing the two underlying indictors is needed for the employment of the term 'political governance'. In other words, it is inappropriate to use some concepts of governance without the employment of some preliminary techniques to bundle constituents of governance variables into composite/representative indicators. Hence, the inquiry contributes to the literature on consequences of terrorism on the one hand and to the growing literature on measuring governance on the other hand. We use both composite and sub-components of governance variables in order to increase room for policy implications.

The remainder of the paper is structrued as follows. Section 2 discusses and clarifies the theoretical and empirical underpinnings of governance concepts. The data and methodology are covered in Section 3. Section 4 presents the empirical results. Section 5 concludes with policy implications.

\section{Clarification of governance and theoretical underpinnings}

\subsection{Clarification of governance}

In this section, we elicit governance concepts. Consistent with Asongu (2016), governance is a multidimensional and complex phenomenon that has many definitions.

First, Dixit (2009, p. 5) defines economic governance as '... structure and functioning of the legal and social institutions that support economic activity and economic 
transactions by protecting property rights, enforcing contracts, and taking collective action to provide physical and organizational infrastructure'.

Second, according to Fukuyama (2013), a more comprehensive notion of governance encompasses four main features, namely: procedural measures, output measures, indicators of capacity that entail professionalism and resources and bureaucratic measures.

Third, consistent with Tusalem (2015), the notion of governance embodies: bureaucratic effectiveness, corruption-control, the rule of law, regulation quality and political stability.

Fourth, models of governance from Kaufmann et al. (2010) have been the most widely employed in the literature. Three main indicators of governance are suggested by the authors, namely political, economic and institutional dynamics. (i) Political governance is defined as the election and replacement of political leaders. It is measured by two indicators: political stability/no violence and voice and accountability. (ii) Economic governance is defined as the formulation and implementation of policies that deliver public commodities. It is also measured by two indicators: regulation quality and government effectiveness. (iii) Institutional governance is defined as the respect by the State and citizens of institutions that govern interactions between them. Again, it is measured by two variables: corruption-control and the rule of law.

Despite the wide acceptance enjoyed by the indicators from Kaufmann et al. (2010), several criticisms have been levelled on the quality of these measures from scholarly circles. However, Mastruzzi, Kraay and Kaufmann have been providing prompt rebuttals to such criticisms in order to provide assurances in the confidence enjoyed by their governance variables. The debate by Marcus Kurtz and Andrew Schrank is one of the most notable in the literature. For lack of space, interested readers can find insights into the debate in: 'models, measures and mechanisms"; a reply; a defense and a rejoinder (Kurtz \& Schrank, 2007ab; Kaufmann et al., 2007ab). In the discussion of empirical underpinnings and analysis that follow, our conception and definition of governance is consistent with Kaufmann et al. (2010).

\subsection{Empirical literature}

According to Enders and Sandler (2006), terrorism can be understood as threatened use of force by sub-national actors for the goal of employing intimidation to secure political goals. Hence, by definition terrorism is designed to either influence political governance positively or negatively. But we argue that the definition could also be extended to economic 
and institutional governances. On the one hand, terrorism can influence economic governance because it is logical to resort to violence as means of manifesting grievances on the poor formulation and implementation of policies that deliver public commodities. Such terror may either affect economic governance positively or negatively. On the other hand, terrorism can also influence institutional governance when the State fails to respect institutions that govern interactions between citizens and the State. The outcome could also either be positive or negative. The empirical underpinnings linking terrorism and governance can be discussed in three main branches: (i) linkages between domestic terrorism and governance; (ii) the nexus between governance and transnational terrorism and (iii) relationships between governance and terrorism.

First, on the relationship with domestic terrorism, Choi (2010) argued that governance is related to domestic terrorism in the view that ordinary citizens are gifted with incentives to use violence against the government, institutions, other citizens and political figures under three scenarios, namely, when they: (i) hold grievances, (ii) find no peaceful avenues of solving grievances, hopelessness and sentiments of desperation and (iii) perceive the employment of terror as a legitimate and viable action of last resort to communicate their anger and frustration. The bases of this logic is founded on the intuition that citizens would use terrorism as a pragmatic means to influencing governance in the absence of peaceful mechanisms for resolving conflicts and/or manifesting their grievances. Within this framework, we postulate that citizens are likely to use terror channels to influence political, economic and institutional governances, when they lack peaceful options with which to communicate their grievances.

Second, on the link between transnational terrorism and governance, in light of the discourse already provided in the first strand, good governance is also expected to consolidate political, economic and institutional systems that on the one hand protect both citizens and foreigners and that on the other hand, avail nonviolent channels by which conflicts can be resolved (Choi, 2010). Moreover, transnational terrorism can influence domestic governments to improve their governance standards in order to prevent further escalation and contagion of domestic terrorism. The connection between transnational terrorism and governance is logical because transnational terrorism can be used to influence foreign policy by domestic governments. This is consistent with the findings of Savun and Phillips (2009) which showed that transnational terrorism is associated with foreign policy (regardless of political regime types). According to the narrative, a country's foreign policy influences resentment abroad 
and transnational terrorism can be used as means for influencing domestic governments to alter their foreign policies.

In the light of foundations in the first-two strands, terrorism can induce, among others (i) political governance or free and fair democratic process for the election and replacement of political leaders; (ii) economic governance or the formulation and implementation of policies that provide public goods to citizens and (iii) institutional governance or the respect by citizens and the State of institutions that govern interactions between them.

The third strand engages some debate surrounding the nexus between terrorism and governance. Following Hoffman et al. (2013), studies on the relationship between crossnational terrorism and governance are founded on the scholarship that opportunities of violence can be used against regime-based disparities. Within this framework, terrorism is more likely to be used against bad governance than good governance. However, it is important to balance this description with the view that good governance offers more opportunities of dealing with grievances and some recalcitrant citizens might abuse such liberties by employing violence as a means of making their complaints heard.

Moreover, terror is likely to be employed to influence governance in failed and/or failing states than in stable autocracies (see Schmid, 1992; Eubank \& Weinberg (1994); Drakos \& Gofas, 2006; Piazza, 2007; Lai 2007; Piazza 2008a). Conversely, political access theories (see Eyerman, 1998) argue that the relationship between good governance and terrorism is weak because of features like judicial independence (Findley \& Young, 2011); rule of law (Choi, 2010) and better conditions for conflict management (Li, 2005).

From an empirical standpoint, the linkage between transnational terrorism and democratic institutions of government has been substantially documented (Eubank \& Weinberg, 1994, 2001; Piazza, 2007, 2008b; Weinberg \& Eubank, 1998; Lee, 2013). Additionally, Chenoweth (2010) argued that good governance with democratic competition could provide a conducive environment for violent actions. According to Li (2005), two competing impacts of democracy are apparent. On the one hand, constraints in government can increase transnational terrorism owing to deadlock from checks and balances. On the other, democratic participation reduces incidents of transnational terrorism.

Noticeably, much of the empirical literature has focused on the effect of governance on terrorism. In the light of discussed empirical underpinnings, we contribute to the literature by assessing the reverse relationship. 


\subsection{Stylized facts and theoretical underpinnings}

\subsubsection{Intuition and theoretical underpinnings}

In this section, we discuss the intuition and theoretical underpinnings showing why a country besieged by terrorism may have concerns associated with political governance, economic governance and institutional governance. These three dimensions of governance are discussed in turn.

Consistent with the literature (Laver \& Shepsle, 1998; Williams, 2012), some specific terrorist events affect political governance. First, events of terrorism could influence the policy options adopted by political parties owing to shifting interests in constituencies. As substantiated by Indridason (2008), when confronted with incidents of terrorism, political coalitions are more likely to be created. Accordingly, it is more probable that political entities which share common policy options create coalitions in order to meet common public demands in the face of terrorism. Second, terrorism can change the political climate and raise the stakes of some policies that are prioritised by the political agenda. Third, there is a substantial body of literature which maintains that incidences of terrorism affect election anticipations because voters are likely to punish governing parties for ensuring their protection (see Berrebi \& Klor, 2006; Siqueira \& Sandler, 2007). The fact that terrorism influences political governance in terms of voice and accountability and political stability/no violence has been confirmed in recent empirical literature (Indridason, 2008; Williams, 2012). Some country-specific cases where terrorism has affected political governance include: (i) the United States of America after the September 11 ${ }^{\text {th }}, 2001$ attack (Jacobson, 2003; Langer \& Cohen, 2005) and (ii) Turkey where terror incidents influence the outcome of political elections (Kibris, 2010).

Terrorism is also very likely to influence economic governance activities because it affects both government effectiveness and regulation quality. From an economic governance perspective, it affects the ability of the government to effectively implement policies that are designed to deliver public commodities. For example, as documented by Tabor (2016), terrorism in the Delta region of Nigeria has been substantially constrained the ability of the government to provide public goods to citizens of the area.

With regard to institutional governance, the respect by the State and citizens of institutions that govern interactions between them is less likely to occur in the presence of terrorism. Notable contemporary examples include: the Libyan experience which has almost become a failed State and the lawlessness in some parts of Northern Nigeria where the influence of Boko Haram still pervades. Efobi and Asongu (2016) have recently shown that 
terrorism decreases the rule of law and increases corruption which, inter alia, reduces institutional governance and increases capital flight.

\subsubsection{Stylized facts supporting theoretical underpinnings and testable hypotheses}

Figures 1-3 below respectively show relationships between various governance dynamics and terrorism variables. In essence Figure 1 illustrates linkages between domestic terrorism and governance while Figure 2 shows corresponding relationships between transnational terrorism and governance. Finally, the nexus between institutional governance and unclear terrorism is disclosed in Figure 3. We consistently observe that a negative linkage is apparent when graphs are viewed both vertically and horizontally. However, it is important to note that the negative relationship between terrorism and governance is most apparent with political governance. Hence while the graphs substantiate the intuition and theoretical underpinnings on a negative relationship between governance and terrorism, such a negative linkage may be most significant between terrorism and political governance. This is essentially because from the stylized facts, the governance dynamic with the highest sensitivity to terrorism is political governance. We attempt to validate this perception with additional proof in the empirical section. The corresponding hypothesis to be tested is the following.

Hypothesis: Compared to economic governance and institutional governance, political governance is most sensitive to all dynamics of terrorism.

Figure 1: Domestic terrorism (Domter) and governance

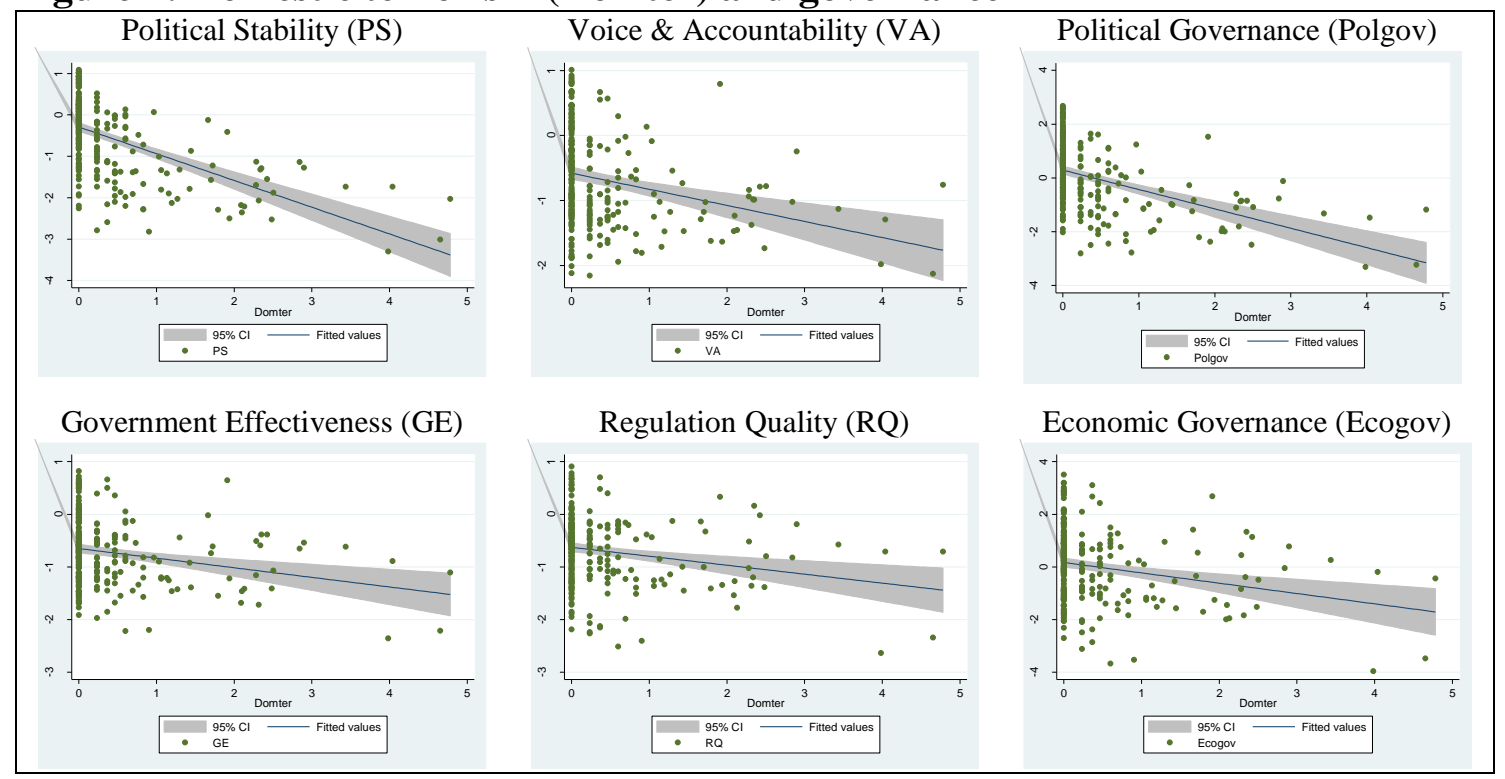




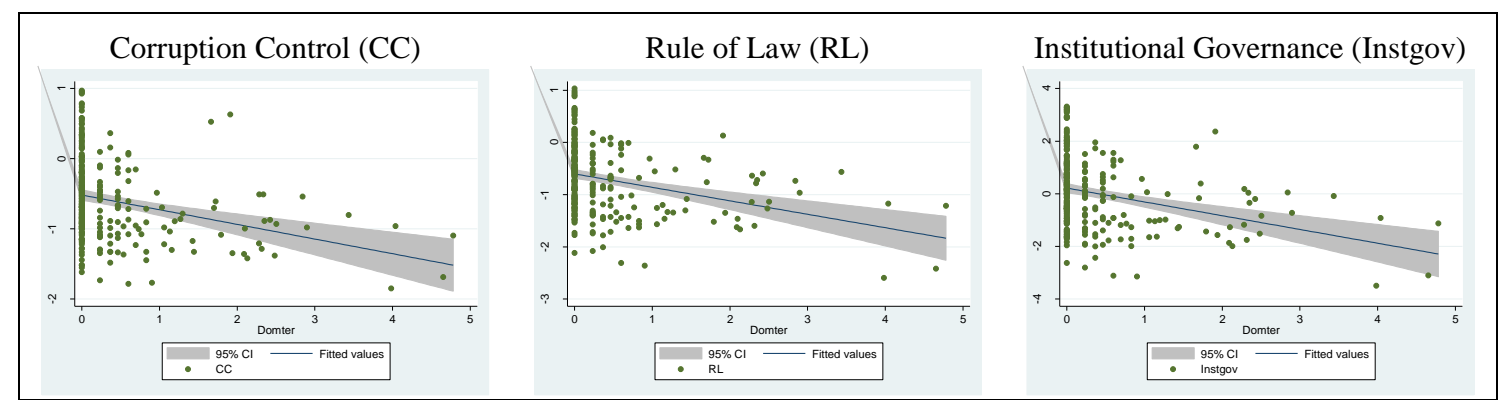

Source: Authors

Figure 2: Transnational terrorism (Transter) and governance

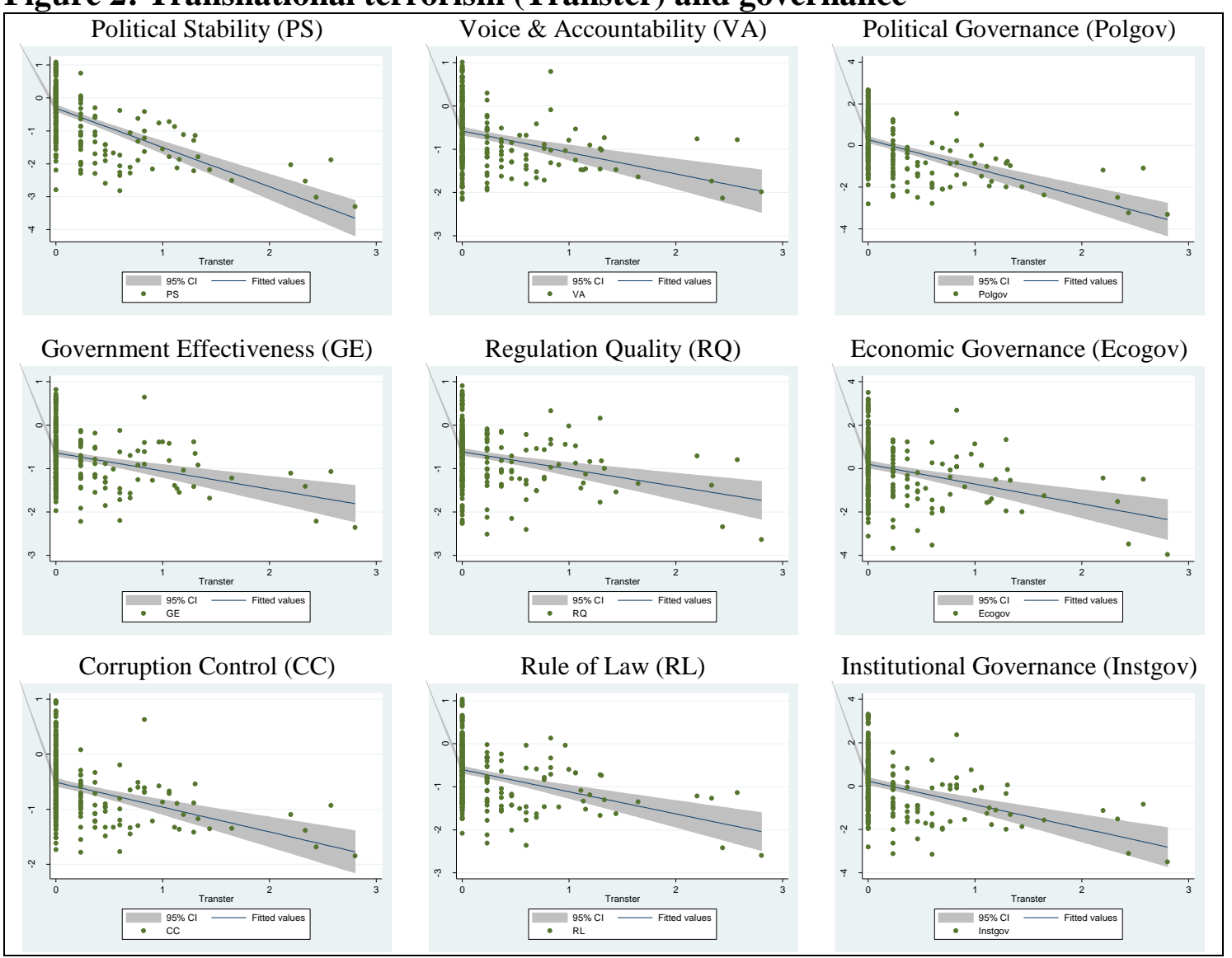

Source: Authors

Figure 3: Unclear terrorism (Unter) and governance

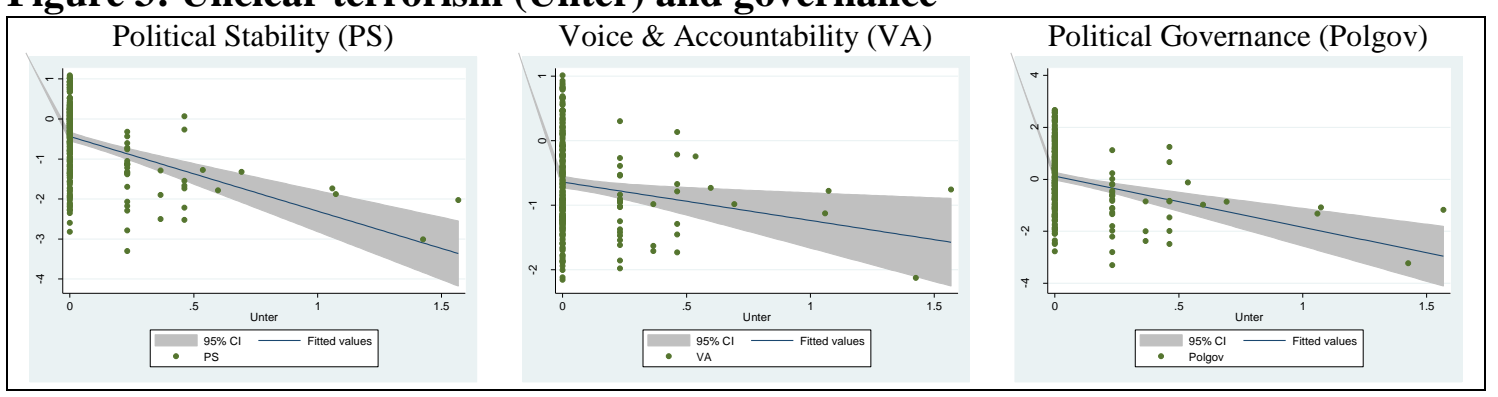




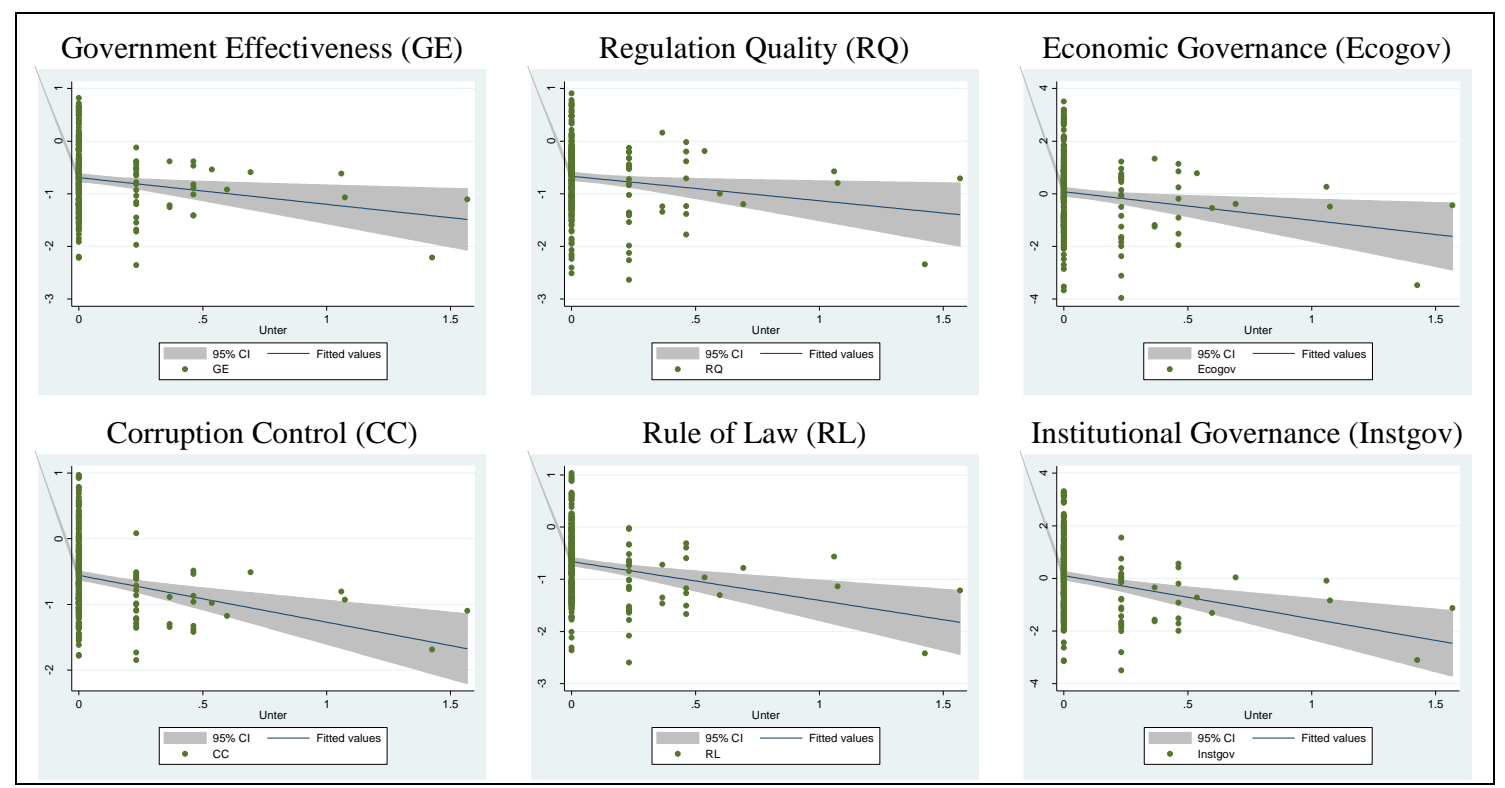

Source: Authors

\section{Data and Methodology}

\subsection{Data}

We investigate a panel of 53 African countries with data for the period 1998-2012 from: (i) the Global Terrorism Database, (ii) African Development Indicators (ADI) and World Governance Indicators of the World Bank and (iii) terrorism incidents from Enders et al. (2011) and Gailbulloev et al. (2012). The periodicity under investigation ends in the year 2012 because of data availability constraints, notably: (i) macroeconomic and institutional indicators from the ADI of the World Bank on the one hand and (ii) terrorism variables from Enders et al. (2011) and Gailbulloev et al. (2012) on the other. The period of study starts from 1998 because governance variables from World Governance Indicators are only available from the year 1996. The year 1998 is chosen in order to enable the computation of three year non-overlapping data averages. The interest of using three-year data averages is to limit instrument proliferation (see the estimation technique Section 3.2.2) and mitigate short-run disturbances that may loom substantially (Islam, 1995, p. 323). Hence, we have five threeyear non-overlapping intervals: 1998-2000; 2001-2003; 2004-2006; 2007-2009 and 20102012. The focus on Africa is because some of the lowest levels of quality of governance are likely to be found there (Mo Ibrahim Foundation, 2015). Moreover, the high frequency of civil wars and political strife in this continent has left a legacy of poor governance (Boyce \& O’Donnell, 2007; Boyce \& Forman, 2010). 
The dependent variables are six unbundled governance indicators; namely: the rule of law, corruption-control, regulation quality, government effectiveness, voice and accountability and political stability plus four bundled measures, notably political governance, economic governance, institutional governance and general governance. While the first-six are individual governance measures from Kaufmann et al. (2010), the last-four are composite indicators that are combined by means of the Principal Component Analysis (PCA) technique (discussed in Section 3.2.1) ${ }^{1}$. Such unbundled (Gani, 2011; Andrés et al., 2015; Yerrabit \& Hawkes, 2015) and bundled governance (Asongu, 2015, 2016) variables are increasingly being used in the literature ${ }^{2}$.

Terrorism is defined in this study as the actual and threatened use of force by subnational actors with the purpose of employing intimidation to meet political objectives (Enders \& Sandler, 2006). Four different but connected terrorism dependent indicators are used. They are: (i) dynamics of domestic, (ii) transnational, (iii) unclear and (iv) total terrrorism. These endogenous variables account for most of the numbers of yearly terrorism incidents registered in a country within a year. In order to prevent mathematical concerns relating to the log-transformation of zeros and correction of the positive skewness in our data distribution, the study takes the natural logarithm of terrorism incidents by adding one to the base number. This conversion approach is consistent with recent literature (Choi \& Salehyan, 2013; Bandyopadhyay et al., 2014). Terrorism-specific definitions are from Efobi et al. (2015, p. 6). Domestic terrorism "includes all incidences of terrorist activities that involves the nationals of the venue country: implying that the perpetrators, the victims, the targets and supporters are all from the venue country" (p.6). Transnational terrorism is "terrorism including those acts that concern at least two countries. This implies that the perpetrator, supporters and incidence may be from/in one country, but the victim and target is from another". Unclear terrorism is that, "which constitutes incidences of terrorism that can

\footnotetext{
${ }^{1}$ It is important to clarify how the definition and conceptualization of political governance may affect the operationalization of the dependent variable. This is essentially because one of its constituents (i.e. 'political stability/no violence') is conceptually linked to terrorism. Political governance is different from terrorism on three main counts. First, they are different by conception and definition as outlined in the study. Second, they represent different policy signals. Whereas terrorism is a negative signal, political governance is a positive signal. Third, whereas a component of political governance (i.e. 'political stability/no violence') may be related to terrorism, from a conceptual standpoint, corresponding definitions and signals (positive versus negative) are different. Moreover, political stability/no violence is complemented with 'voice and accountability' (which is conceptually distinct from terrorism) to produce 'political governance'. In summary, of the ten governance indicators employed, the concern about definition/conceptualization which we have clarified is only related to one dependent variable.

${ }^{2}$ While we have highlighted the criticisms and corresponding rebuttals on the governance indicators in Section 2, the choice of the governance indicators from the World Bank is because of: (i) the wide usage of such variables in the literature and (ii) the fact that the variables are freely accessible. Moreover, we do not have the financial means to purchase alternative governance variables from the International Country Risk Guide.
} 
neither be defined as domestic nor transnational terrorism" (p.6). Total terrorism is the sum of domestic, transnational and unclear terrorisms ${ }^{3}$.

In order to ensure that estimated results are not biased by omitted variables, this paper includes seven control variables. They comprise (i) a lagged governance variable, (ii) internet penetration, (iii) Gross Domestic Product (GDP) growth, (iv) inflation rate, (v) foreign direct investment (FDI), (vi) education and (vii) government expenditure. Information technologies including the internet and mobile phones have been documented to increase government quality because they improve space for accountability and transparency (Boulianne, 2009; Snow, 2009; Diamond, 2010; Grossman et al., 2014). Countries with high income levels have also been documented to be associated with higher levels of government quality in Africa (Asongu, 2012, p.191). Rising consumer prices are very likely to influence governance by prompting authorities to device and implement policies that keep food prices in-check. Financial globalisation in the perspective of FDI has been recognised to positively affect political governance (Lalountas et al., 2011). Lederman et al. (2005) and Cheung and Chan (2008) have established that education increases governance indicators. Government expenditure is also strongly associated with improvement governance measures (Asongu \& Nwachukwu, 2016a). Definitions of variables are provided in Appendix 1, the summary statistics in Appendix 2 and the correlation matrix in Appendix $3^{4}$.

\subsection{Methodology}

\subsubsection{Principal Component Analysis (PCA)}

In accordance with recent governance (Asongu \& Nwachukwu, 2016b) and development (Tchamyou, 2016) literature, this study employs PCA in order to bundle governance indicators. The PCA is a widely employed statistical approach that is used to reduce a set of highly correlated variables into a smaller set of uncorrelated variables known as principal components (PCs). Consistent with the motivation of this study, it is important to note that the bundling of governance indicators is also to clarify some governance concepts

\footnotetext{
3 The purpose of using multiple types of terrorism variables is consistent with recent terrorism literature (Bandyopadhyay et al., 2014; Asongu \& Nwachukwu, 2017). Moreover, in order to increase room for policy implications, it is important to engage the available terrorism and governance indicators. Such should reduce errors associated from variable-selection bias.

${ }^{4}$ While there might be concerns that the control variables could also correlate with some of the causal mechanisms by which terrorism influences governance, the following three points clarify the concerns: (i) the degree of substitution among control variables is low; (ii) the degree of substitution between terrorism and the control variables is not high and (iii) the Generalised Method of Moments technique is designed to address concerns of simultaneity through the process of instrumentation.
} 
that are employed without statistical relevance. The high degree of substitution between governance variables is disclosed in Appendix 3. The criterion for the retention of common factors is from Kaiser (1974) and Jolliffe (2002). The authors have recommended the retention of PCs with an eignvalue higher than the mean.

From Table 1, it is apparent that the first PC of general governance is 4.787 with a corresponding percentage of variation of $79.7 \%$. This implies that approximately $79 \%$ of variations from the six governance variables are contained in the composite governance variable (G.gov). The narrative on total variations and eigenvalues is in line with other combined governance indicators; namely: political governance (Polgov) which has more than $82 \%$ of variation and an eigenvalue of 1.647; economic governance (Ecogov) has an eigenvalue of 1.863 with more than $93 \%$ of variation from constituent indicators and institutional governance (Instgov) displays an eigenvalue of 1.867 with approximately $94 \%$ of information contained in the corruption-control and the rule of law variables.

Instgov (or institutional governance) is the respect by the State and citizens of institutions that govern interactions between them. Ecogov (or economic governance) is the formulation and implementation of policies that deliver public commodities. Polgov (or political governance) is defined as the election and replacement of political leaders. The definitions are consistent with the governance literature (Kaufmann et al., 2007ab, 2010; Andrés et al., 2015) ${ }^{5}$.

Table 1: Principal Component Analysis (PCA) for Governance (Gov)

\begin{tabular}{|c|c|c|c|c|c|c|c|c|c|}
\hline \multirow{2}{*}{$\begin{array}{c}\text { Principal } \\
\text { Components }\end{array}$} & \multicolumn{6}{|c|}{ Component Matrix(Loadings) } & \multirow[t]{2}{*}{ Proportion } & \multirow{2}{*}{$\begin{array}{l}\text { Cumulative } \\
\text { Proportion }\end{array}$} & \multirow{2}{*}{$\begin{array}{l}\text { Eigen } \\
\text { Value } \\
\end{array}$} \\
\hline & VA & PS & RQ & GE & $\mathbf{R L}$ & $\mathrm{CC}$ & & & \\
\hline First PC (G.Gov) & 0.385 & 0.370 & 0.412 & 0.426 & 0.440 & 0.412 & 0.797 & 0.797 & 4.787 \\
\hline Second PC & 0.093 & 0.850 & -0.364 & -0.343 & 0.007 & -0.140 & 0.072 & 0.870 & 0.437 \\
\hline Third PC & 0.862 & -0.179 & 0.122 & -0.192 & -0.182 & -0.373 & 0.058 & 0.929 & 0.353 \\
\hline First PC (Polgov) & 0.707 & 0.707 & --- & --- & --- & --- & 0.823 & 0.823 & 1.647 \\
\hline Second PC & -0.707 & 0.707 & --- & --- & --- & --- & 0.176 & 1.000 & 0.352 \\
\hline First PC (Ecogov) & --- & --- & 0.707 & 0.707 & --- & --- & 0.931 & 0.931 & 1.863 \\
\hline Second PC & --- & --- & -0.707 & 0.707 & --- & --- & 0.068 & 1.000 & 0.137 \\
\hline First PC (Instgov) & --- & --- & --- & --- & 0.707 & 0.707 & 0.933 & 0.933 & 1.867 \\
\hline Second PC & --- & --- & --- & --- & -0.707 & 0.707 & 0.066 & 1.000 & 0.132 \\
\hline
\end{tabular}

P.C: Principal Component. VA: Voice \& Accountability. RL: Rule of Law. R.Q: Regulation Quality. GE: Government Effectiveness. PS: Political Stability. CC: Control of Corruption. G.Gov (General Governance): First PC of VA, PS, RQ, GE, RL \& CC. Polgov (Political

\footnotetext{
${ }^{5}$ The fact that we do not retain more than one principal component for a given governance dynamic is consistent with recent governance literature (Asongu \& Nwachukwu, 2016c). Accordingly, for some governance indicators (e.g. institutional governance and economic governance), the first PC contains more than $93 \%$ of common information in the constituent indicators. We do not find the remaining $7 \%$ very significant. Moreover, if we are to use a second principal component representing the $7 \%$ variation, we shall need to provide a 'governance name' to it (e.g. 'Economic Governance 2' given that 'Economic Governance 1' corresponds to the first principal with a $93 \%$ variation).
} 
Governance): First PC of VA \& PS. Ecogov (Economic Governance): First PC of RQ \& GE. Instgov (Institutional Governance): First PC of RL \& CC.

\subsubsection{Estimation specification}

At least five factors motivate the choice of the Generalized Method of Moments (GMM) (Asongu \& De Moor, 2017). First, the dependent variables should be persistent. As shown in Appendix 4, the correlation between the dependent variables and their first lags is higher than the rule of thumb threshold of 0.800 that is required to establish persistence in dependent variables. Second, the number of countries (N) is higher than the number of years per country $(\mathrm{T})$. Hence, the sample of the study is consistent with the $\mathrm{N}(53)>\mathrm{T}(5)$ criterion.

Third, the estimation strategy accounts for endogeneity in the all regressors. Fourth, crosscountry variations are not eliminated with the estimation approach. Fifth, the system GMM technique corrects for biases in small samples that are inherent in the difference estimator. It is fundamentally for this fifth reason that Bond et al. (2001, pp. 3-4) have recommended that the system GMM estimator (Arellano \& Bover, 1995; Blundell \& Bond, 1998) be preferred to the difference estimator (Arellano \& Bond, 1991).

Within the specific context of this study, the Arellano and Bover (1995) extension by Roodman (2009ab) is adopted. The strategy employs forward orthogonal deviations in place of first differences. The estimation strategy has been documented to restrict overidentification (or limit instrument proliferation) and account for cross sectional dependence (see Love \& Zicchino, 2006; Baltagi, 2008). In the specification strategy, a two-step approach is adopted in place of the one-step because it controls for heteroscedasticity.

The following equations in levels (1) and first difference (2) summarize the standard system GMM estimation procedure.

$$
\begin{aligned}
G_{i, t}=\sigma_{0}+ & \sigma_{1} G_{i, t-\tau}+\sigma_{2} T_{i, t}+\sum_{h=1}^{6} \delta_{h} W_{h, i, t-\tau}+\eta_{i}+\xi_{t}+\varepsilon_{i, t} \\
G_{i, t}-G_{i, t-\tau}= & \sigma_{1}\left(G_{i, t-\tau}-G_{i, t-2 \tau}\right)+\sigma_{2}\left(T_{i, t}-T_{i, t-\tau}\right)+ \\
& +\sum_{h=1}^{6} \delta_{h}\left(W_{h, i, t-\tau}-W_{h, i, t-2 \tau}\right)+\left(\xi_{t}-\xi_{t-\tau}\right)+\varepsilon_{i, t-\tau}
\end{aligned}
$$

Where: $G_{i, t}$ is a governance indicator (political, economic or institutional governance) of country $i$ at period $t ; T_{i, t}$, is a terrorism variable (domestic, transnational, unclear and total); $\sigma_{0}$ is a constant; $\tau$ represents tau; $W$ is the vector of control variables (internet penetration, 
GDP growth, inflation, foreign direct investment, education and government expenditure); $\eta_{i}$ is the country-specific effect, $\xi_{t}$ is the time-specific constant and $\varepsilon_{i, t}$ the error term.

\subsubsection{Identification and exclusion restriction}

We treat all independent variables as predetermined or suspected endogenous variables (Love \& Zicchino, 2006; Dewan \& Ramaprasad, 2014). Therefore, the gmmstyle is adopted for them and only years are treated as exogenous and the approach for treating the ivstyle (years) is 'iv(years, eq(diff))' because it is not possible for the years to become endogenous in first-difference (see Roodman, 2009b).

In order to tackle the issue of simultaneity, lagged regressors are used as instruments for forward-differenced indicators. Hence, in order to eliminate fixed impacts that could affect the investigated connections, Helmet transformations are performed for the regressors, in line with Love and Zicchino (2006) and Arellano and Bover (1995). These conversions consist of forward mean-differencing of the indicators: instead of subtracting the previous observation for the contemporaneous one (see Roodman, 2009b, p. 104), the mean of all future observations are deducted from the variables.

The adjustment ensures parallel and orthogonal conditions between the forwarddifferenced and lagged values. Regardless of the number of lags, in order to minimise loss of data, the underlying transformations are computed for all observations with the exception of the last for each cross-section "And because lagged observations do not enter the formula, they are valid as instruments" (Roodman, 2009b, p. 104).

In this study, the impact of instruments or years is considered as having strictly exogenous influence on the chosen governance indicators exclusively through the endogenous variables. The statistical validity of the exclusion restriction is examined with the Difference in the Hansen Test (DHT) for the exogeneity of instruments. Whereas in a standard instrumental variable (IV) approach, rejection of the alternative hypothesis of the Sargan Overidentifying Restrictions (OIR) test implies that the instruments do not clarify the dependent variable beyond the proposed mechanisms (see Beck et al., 2003; Asongu \& Nwachukwu, 2016d), the DHT is the information criterion in the GMM approach because it examines if years as an instrument exhibit strict exogeneity. Therefore, the exclusion restriction is confirmed if the alternative hypothesis of the DHT corresponding to IV (year, eq(diff)) is rejected. 


\section{Empirical analysis}

\subsection{Presentation of results}

Table 2, Table 3, Table 4 and Table 5 respectively present findings corresponding to political governance, economic governance, institutional governance and general governance. For each table, four principal information criteria are employed to examine the validity of GMM models with forward orthogonal deviations ${ }^{6}$. Judging from these criteria, the estimated models and corresponding instruments are overwhelmingly valid.

The following findings are established from Table 2. All terrorism dynamics negatively affect political governance and its constituents, with the negative magnitudes higher from transnational terrorism compared to domestic terrorism. In Table 3, some models are not valid because of post-estimation presence of autocorrelation in the residuals. The negative terrorism-governance linkages are only scantily apparent in: (i) transnational terrorism for regulation quality, (ii) domestic and total terrorism for government effectiveness and (iii) transnational terrorism for government effectiveness. Ultimately, transnational terrorism consistently negatively affects economic governance and its components. In Table 4, institutional governance and its elements are not significantly affected by terrorism dynamics whereas in Table 5, the negative effects are only apparent from transnational and total terrorisms. The significant control variables have expected signs for the most part.

\footnotetext{
6 "First, the null hypothesis of the second-order Arellano and Bond autocorrelation test (AR(2)) in difference for the absence of autocorrelation in the residuals should not be rejected. Second the Sargan and Hansen overidentification restrictions (OIR) tests should not be significant because their null hypotheses are the positions that instruments are valid or not correlated with the error terms. In essence, while the Sargan OIR test is not robust, but not weakened by instruments, the Hansen OIR is robust but weakened by instruments. In order to restrict identification or limit the proliferation of instruments, we have ensured that instruments are lower than the number of cross-sections in most specifications. Third, the Difference in Hansen Test (DHT) for exogeneity of instruments is also employed to assess the validity of results from the Hansen OIR test. Fourth, a Fischer test for the joint validity of estimated coefficients is also provided" (Asongu \& De Moor, 2017, p.200)
} 
Table 2: Political Governance and Terrorism

Dependent Variables: Political Governance Dynamics

Voice and Accountability (VA)

Political Stability (PS)

Political Governance (Polgov)

\begin{tabular}{|c|c|c|c|c|c|c|c|c|c|c|c|c|}
\hline Constant & $\begin{array}{l}-0.104 * * \\
(0.024)\end{array}$ & $\begin{array}{l}-0.119 * * \\
(0.020)\end{array}$ & $\begin{array}{l}-0.138 \\
(0.004)\end{array}$ & $\begin{array}{l}-0.099 * * \\
(0.041)\end{array}$ & $\begin{array}{l}-0.331 * * * \\
(0.002)\end{array}$ & $\begin{array}{l}-0.277^{* * * *} \\
(0.001)\end{array}$ & $\begin{array}{l}-0.191 \\
(0.121)\end{array}$ & $\begin{array}{l}-0.316 * * * * \\
(0.001)\end{array}$ & $\begin{array}{l}-0.190 \\
(0.124)\end{array}$ & $\begin{array}{l}-0.125 \\
(0.117)\end{array}$ & $\begin{array}{l}-0.128 \\
(0.402)\end{array}$ & $\begin{array}{l}-0.128 \\
(0.297)\end{array}$ \\
\hline $\mathrm{VA}(-1)$ & $\begin{array}{l}0.959 * * * \\
(0.000)\end{array}$ & $\begin{array}{l}0.942 * * * \\
(0.000)\end{array}$ & $\begin{array}{l}0.974 * * * \\
(0.000)\end{array}$ & $\begin{array}{l}0.947 * * * \\
(0.000)\end{array}$ & --- & -- & -- & -- & -- & -- & -- & -- \\
\hline PS $(-1)$ & --- & --- & --- & --- & $\begin{array}{l}0.798 * * * \\
(0.000)\end{array}$ & $\begin{array}{l}0.819 * * * \\
(0.000)\end{array}$ & $\begin{array}{l}0.771 * * * * \\
(0.000)\end{array}$ & $\begin{array}{l}0.699 * * * * \\
(0.000)\end{array}$ & --- & --- & --- & --- \\
\hline Polgov(-1) & --- & --- & --- & --- & -- & --- & -- & -- & $\begin{array}{l}0.987 * * * \\
(0.000)\end{array}$ & $\begin{array}{l}0.934 * * * \\
(0.000)\end{array}$ & $\begin{array}{l}0.938^{* * * *} \\
(0.000)\end{array}$ & $\begin{array}{l}0.980^{* * * *} \\
(0.000)\end{array}$ \\
\hline Domestic Terrorism & $\begin{array}{l}-0.043 * * * \\
(0.000)\end{array}$ & --- & --- & --- & $\begin{array}{l}-0.154 * * * \\
(0.000)\end{array}$ & --- & --- & --- & $\begin{array}{l}-0.109 * * * \\
(0.002)\end{array}$ & --- & --- & --- \\
\hline Transnational Terrorism & --- & $\begin{array}{l}-0.100 * * * \\
(0.000)\end{array}$ & --- & --- & --- & $\begin{array}{l}-0.464 * * * \\
(0.000)\end{array}$ & --- & --- & -- & $\begin{array}{l}-0.385 * * * \\
(0.000)\end{array}$ & --- & --- \\
\hline Unclear Terrorism & --- & --- & $\begin{array}{l}-0.169 * * * \\
(0.008)\end{array}$ & --- & --- & --- & $\begin{array}{l}-0.543 * * * \\
(0.000)\end{array}$ & --- & --- & --- & $\begin{array}{l}-0.372 * * * * \\
(0.000)\end{array}$ & --- \\
\hline Total Terrorism & --- & --- & --- & $\begin{array}{l}-0.045^{* * *} \\
(0.001)\end{array}$ & --- & --- & --- & $\begin{array}{l}-0.232 * * * * \\
(0.000)\end{array}$ & --- & --- & --- & $\begin{array}{l}-0.151 * * * * \\
(0.000)\end{array}$ \\
\hline Internet & $\begin{array}{l}0.005 * * * \\
(0.003)\end{array}$ & $\begin{array}{l}0.005 * * * \\
(0.000)\end{array}$ & $\begin{array}{l}0.007 * * * \\
(0.000)\end{array}$ & $\begin{array}{l}0.005 * * * * \\
(0.001)\end{array}$ & $\begin{array}{l}-0.002 \\
(0.525)\end{array}$ & $\begin{array}{l}0.006 * * \\
(0.022)\end{array}$ & $\begin{array}{l}0.004 \\
(0.132)\end{array}$ & $\begin{array}{l}-0.0009 \\
(0.774)\end{array}$ & $\begin{array}{l}0.008 * * \\
(0.035)\end{array}$ & $\begin{array}{l}0.014 * * * \\
(0.000)\end{array}$ & $\begin{array}{l}0.011 * * * \\
(0.000)\end{array}$ & $\begin{array}{l}0.011^{* * * *} \\
(0.002)\end{array}$ \\
\hline GDP growth & $0.015^{* *}$ & 0.007 & $0.016 * *$ & $0.012^{* *}$ & $\begin{array}{l}0.016 * \\
(0.090)\end{array}$ & $\begin{array}{l}0.006 \\
(0.373)\end{array}$ & $\begin{array}{l}0.003 \\
(0.706)\end{array}$ & $\begin{array}{l}0.004 \\
(0.598)\end{array}$ & $\begin{array}{l}0.036 * * * * \\
(0.007)\end{array}$ & $\begin{array}{l}0.022 \\
(0.106)\end{array}$ & $\begin{array}{l}0.017 \\
(0.110)\end{array}$ & $\begin{array}{l}0.031 * * \\
(0.023)\end{array}$ \\
\hline Inflation & $\begin{array}{l}\text { (0.012) } \\
0.005 \\
(0.198)\end{array}$ & $\begin{array}{l}\text { (0.1/6) } \\
0.006 \\
(0.327)\end{array}$ & $\begin{array}{l}(0.015) \\
0.008^{*} \\
(0.057)\end{array}$ & $\begin{array}{l}(0.041) \\
0.004 \\
(0.222)\end{array}$ & $\begin{array}{l}0.017 * * * * \\
(0.001)\end{array}$ & $\begin{array}{l}0.031 * * * \\
(0.000)\end{array}$ & $\begin{array}{l}(0.007) \\
0.007 \\
(0.242)\end{array}$ & $\begin{array}{l}0.021^{* * * *} \\
(0.000)\end{array}$ & $\begin{array}{l}0.022 * * * * \\
(0.000)\end{array}$ & $\begin{array}{l}0.025^{* * * *} \\
(0.000)\end{array}$ & $\begin{array}{l}0.026^{* * * * *} \\
(0.000)\end{array}$ & $\begin{array}{l}0.024^{* * * *} \\
(0.000)\end{array}$ \\
\hline Foreign investment & $\begin{array}{l}-0.002 \\
(0.117)\end{array}$ & $\begin{array}{l}-0.0008 \\
(0.577)\end{array}$ & $\begin{array}{l}-0.002 \\
(0.223)\end{array}$ & $\begin{array}{l}-0.002 \\
(0.198)\end{array}$ & $\begin{array}{l}-0.003 \\
(0.274)\end{array}$ & $\begin{array}{l}-0.004 \\
(0.253)\end{array}$ & $\begin{array}{l}0.0002 \\
(0.900)\end{array}$ & $\begin{array}{l}-0.004^{*} \\
(0.057)\end{array}$ & $\begin{array}{l}-0.011 * * * * \\
(0.033)\end{array}$ & $\begin{array}{l}-0.007 * \\
(0.097)\end{array}$ & $\begin{array}{l}-0.008 * * \\
(0.031)\end{array}$ & $\begin{array}{l}-0.011 * * * * \\
(0.003)\end{array}$ \\
\hline Education & $\begin{array}{l}-0.001 \\
(0.231)\end{array}$ & $\begin{array}{l}-0.001 \\
(0.281)\end{array}$ & $\begin{array}{l}-0.001 \\
(0.108)\end{array}$ & $\begin{array}{l}-0.001 \\
(0.299)\end{array}$ & $\begin{array}{l}0.002 \\
(0.175)\end{array}$ & $\begin{array}{l}-0.0006 \\
(0.588)\end{array}$ & $\begin{array}{l}0.0001 \\
(0.944)\end{array}$ & $\begin{array}{l}0.003^{*} \\
(0.068)\end{array}$ & $\begin{array}{l}-0.003 \\
(0.234)\end{array}$ & $\begin{array}{l}-0.005^{* *} \\
(\mathbf{0 . 0 3 3})\end{array}$ & $\begin{array}{l}-0.004 * \\
(0.058)\end{array}$ & $\begin{array}{l}-0.004 \\
(0.128)\end{array}$ \\
\hline Government Expenditure & $\begin{array}{l}-0.001 \\
(0.137)\end{array}$ & $\begin{array}{l}-0.00009 \\
(0.871)\end{array}$ & $\begin{array}{l}-0.001 \\
(0.257)\end{array}$ & $\begin{array}{l}-0.001 \\
(0.156)\end{array}$ & $\begin{array}{l}-0.003 * * * * \\
(0.000)\end{array}$ & $\begin{array}{l}-0.001 * * * \\
(0.000)\end{array}$ & $\begin{array}{l}-0.002 * * * * \\
(0.000)\end{array}$ & $\begin{array}{l}-0.002 * * * * \\
(0.000)\end{array}$ & $\begin{array}{l}-0.001 \\
(0.162)\end{array}$ & $\begin{array}{l}-0.0009 * \\
(0.070)\end{array}$ & $\begin{array}{l}-0.000 \\
(0.999)\end{array}$ & $\begin{array}{l}-0.001 \\
(0.129)\end{array}$ \\
\hline $\begin{array}{l}\operatorname{AR}(1) \\
\operatorname{AR}(2) \\
\text { Sargan OIR } \\
\text { Hansen OIR }\end{array}$ & $\begin{array}{l}(0.041) \\
(\mathbf{0 . 9 2 3}) \\
(\mathbf{0 . 2 9 8}) \\
(\mathbf{0 . 1 8 7})\end{array}$ & $\begin{array}{l}(0.021) \\
(\mathbf{0 . 9 7 7 )} \\
(\mathbf{0 . 6 5 6}) \\
(\mathbf{0 . 1 4 3})\end{array}$ & $\begin{array}{l}(0.059) \\
(\mathbf{0 . 7 4 6}) \\
(\mathbf{0 . 3 6 1}) \\
(\mathbf{0 . 1 4 4 )}\end{array}$ & $\begin{array}{l}(0.033) \\
(\mathbf{0 . 9 4 0 )} \\
(\mathbf{0 . 3 7 8}) \\
(\mathbf{0 . 1 7 9 )}\end{array}$ & $\begin{array}{l}(\mathbf{0 . 1 0 1}) \\
(\mathbf{0 . 5 0 7}) \\
(0.030) \\
(\mathbf{0 . 3 1 5})\end{array}$ & $\begin{array}{l}(\mathbf{0 . 1 5 0}) \\
(\mathbf{0 . 9 2 5}) \\
(0.084) \\
(\mathbf{0 . 4 8 9})\end{array}$ & $\begin{array}{l}(0.097) \\
(\mathbf{0 . 9 6 6 )} \\
(\mathbf{0 . 1 3 3}) \\
(\mathbf{0 . 4 2 5})\end{array}$ & $\begin{array}{l}(0.106) \\
(0.351) \\
(0.105) \\
(0.611)\end{array}$ & $\begin{array}{l}(0.062) \\
(\mathbf{0 . 4 9 7}) \\
(0.018) \\
(\mathbf{0 . 5 7 9})\end{array}$ & $\begin{array}{l}(0.030) \\
(\mathbf{0 . 4 9 5 )} \\
(\mathbf{0 . 3 4 6}) \\
(\mathbf{0 . 4 5 3})\end{array}$ & $\begin{array}{l}(0.072) \\
(\mathbf{0 . 3 9 5}) \\
(0.085) \\
(\mathbf{0 . 3 5 5})\end{array}$ & $\begin{array}{l}(0.042) \\
(\mathbf{0 . 5 4 4}) \\
(0.074) \\
(\mathbf{0 . 6 1 7})\end{array}$ \\
\hline $\begin{array}{l}\text { DHT for instruments } \\
\text { (a)Instruments in levels }\end{array}$ & & & & & & & & & & & & \\
\hline H excluding group & $(\mathbf{0 . 3 3 7})$ & $(0.635)$ & $(0.617)$ & $(0.225)$ & $(0.515)$ & $(\mathbf{0 . 3 9 3})$ & $(\mathbf{0 . 3 3 5})$ & $(\mathbf{0 . 3 6 5})$ & $(0.298)$ & $(\mathbf{0 . 8 6 4})$ & $(0.743)$ & $(0.261)$ \\
\hline $\begin{array}{l}\text { Dif(null, H=exogenous) } \\
\text { (b) IV (years, eg(diff)) }\end{array}$ & $(0.183)$ & $(0.067)$ & $(0.071)$ & $(0.237)$ & $(0.241)$ & $(0.513)$ & $(0.479)$ & $(0.686)$ & $(0.705)$ & $(\mathbf{0 . 2 1 8})$ & $(0.190)$ & $(\mathbf{0 . 7 8 2})$ \\
\hline H excluding group & $(0.197)$ & $(0.200)$ & $(0.200)$ & $(0.217)$ & $(0.451)$ & $(0.690)$ & $(0.482)$ & $(0.557)$ & $(0.403)$ & $(0.349)$ & $(0.339)$ & $(\mathbf{0 . 4 3 6})$ \\
\hline Dif(null, $H=$ =xogenous) & $(0.298)$ & $(0.159)$ & $(0.163)$ & $(0.217)$ & (0.136) & (0.111) & $(0.263)$ & (0.559) & $(0.976)$ & (0.718) & $(0.406)$ & $(0.989)$ \\
\hline Fisher & $298.43 * * *$ & $468.8 * * *$ & $442.0 * * *$ & $339.0 * * *$ & $409.06 * * *$ & $789.17 * * *$ & $236.8^{* * * *}$ & $328.77 * * *$ & $237.95 * * *$ & $1522.5^{* * * *}$ & $164.4^{* * * *}$ & $330.1 * * *$ \\
\hline $\begin{array}{l}\text { Instruments } \\
\text { Countries }\end{array}$ & $\begin{array}{l}34 \\
46\end{array}$ & $\begin{array}{l}34 \\
46\end{array}$ & $\begin{array}{l}34 \\
46\end{array}$ & $\begin{array}{l}34 \\
46\end{array}$ & $\begin{array}{l}34 \\
46\end{array}$ & $\begin{array}{l}34 \\
46\end{array}$ & $\begin{array}{l}34 \\
46\end{array}$ & $\begin{array}{l}34 \\
46\end{array}$ & $\begin{array}{l}34 \\
46\end{array}$ & $\begin{array}{l}34 \\
46\end{array}$ & $\begin{array}{l}34 \\
46\end{array}$ & $\begin{array}{l}34 \\
46\end{array}$ \\
\hline Observations & $\begin{array}{l}40 \\
131\end{array}$ & $\begin{array}{l}40 \\
131\end{array}$ & $\begin{array}{l}40 \\
131\end{array}$ & $\begin{array}{l}40 \\
131\end{array}$ & $\begin{array}{l}40 \\
131\end{array}$ & 131 & 131 & 131 & 131 & 131 & 131 & 131 \\
\hline
\end{tabular}

***,***: significance levels of 10\%, 5\% and 1\% respectively. DHT: Difference in Hansen Test for Exogeneity of Instruments' Subsets. Dif: Difference. OIR: Over-identifying Restrictions (OIR) Test. The significance of bold values is twofold. 1) The significance of estimated coefficients, the Fisher statistics. 2) The failure to reject the null hypotheses of: a) no autocorrelation in the AR(1) and AR(2) tests and; b) the validity of the instruments in the Sargan and Hansen OIR tests. 


\section{Table 3: Economic Governance and Terrorism}

Dependent Variables: Economic Governance Dynamics

Regulation Quality (RQ)

Government Effectiveness (GE)

Economic Governance (Ecogov)

\begin{tabular}{|c|c|c|c|c|c|c|c|c|c|c|c|c|}
\hline Constant & $\begin{array}{l}-0.347 * * * \\
(0.000)\end{array}$ & $\begin{array}{l}-0.211 * * * * \\
(0.002)\end{array}$ & $\begin{array}{l}-0.320 * * * \\
(0.001)\end{array}$ & $\begin{array}{l}-0.347 * * * \\
(0.000)\end{array}$ & $\begin{array}{l}-0.377^{* * * *} \\
(0.000)\end{array}$ & $\begin{array}{l}-0.303 * * * \\
(0.000)\end{array}$ & $\begin{array}{l}-0.382 * * * * \\
(0.000)\end{array}$ & $\begin{array}{l}-0.292 * * * * \\
(0.000)\end{array}$ & $\begin{array}{l}-0.556 * * * * \\
(0.001)\end{array}$ & $\begin{array}{l}-0.453 * * * \\
(0.000)\end{array}$ & $\begin{array}{l}-0.486^{* * * *} \\
(0.005)\end{array}$ & $\begin{array}{l}-0.547 * * * \\
(0.000)\end{array}$ \\
\hline $\mathrm{RQ}(-1)$ & $\begin{array}{l}0.830 * * * \\
(0.000)\end{array}$ & $\begin{array}{l}0.874 * * * \\
(0.000)\end{array}$ & $\begin{array}{l}0.846 * * * \\
(0.000)\end{array}$ & $\begin{array}{l}0.808 * * * * \\
(0.000)\end{array}$ & -- & -- & --- & -- & --- & --- & --- & -- \\
\hline GE(-1) & --- & --- & --- & -- & $\begin{array}{l}0.824 * * * \\
(0.000)\end{array}$ & $\begin{array}{l}0.858 * * * \\
(0.000)\end{array}$ & $\begin{array}{l}0.898 * * * * \\
(0.000)\end{array}$ & $\begin{array}{l}0.830 * * * \\
(0.000)\end{array}$ & --- & --- & --- & --- \\
\hline Ecogov $(-1)$ & --- & -.- & --- & --- & --- & --- & --- & --- & $\begin{array}{l}0.934 * * * \\
(0.000)\end{array}$ & $\begin{array}{l}0.912 * * * \\
(0.000)\end{array}$ & $\begin{array}{l}0.931 * * * \\
(0.000)\end{array}$ & $\begin{array}{l}0.901 * * * \\
(0.000)\end{array}$ \\
\hline Domestic Terrorism & $\begin{array}{l}0.004 \\
(0.819)\end{array}$ & --- & --- & --- & $\begin{array}{l}-0.052 * * * \\
(0.003)\end{array}$ & --- & --- & --- & $\begin{array}{l}0.009 \\
(0.796)\end{array}$ & --- & -- & --- \\
\hline Transnational Terrorism & --- & $\begin{array}{l}-0.093 * * * \\
(0.000)\end{array}$ & --- & --- & --- & $\begin{array}{l}-0.126 * * * * \\
(0.000)\end{array}$ & --- & --- & --- & $\begin{array}{l}-0.184 * * * \\
(0.000)\end{array}$ & --- & --- \\
\hline Unclear Terrorism & --- & -.- & $\begin{array}{l}0.055 \\
(0.228)\end{array}$ & --- & --- & --- & $\begin{array}{l}-0.050 \\
(0.167)\end{array}$ & --- & --- & --- & $\begin{array}{l}0.074 \\
(0.286)\end{array}$ & -.- \\
\hline Total Terrorism & --- & -.- & --- & $\begin{array}{l}-0.0005 \\
(0.976)\end{array}$ & --- & --- & --- & $\begin{array}{l}-0.059 * * * \\
(0.000)\end{array}$ & --- & --- & --- & $\begin{array}{l}-0.027 \\
(0.397)\end{array}$ \\
\hline Internet & $\begin{array}{l}-0.004 * \\
(0.074)\end{array}$ & $\begin{array}{l}0.001 \\
(0.367)\end{array}$ & $\begin{array}{l}-0.003 \\
(0.108)\end{array}$ & $\begin{array}{l}-0.004 * * \\
(0.041)\end{array}$ & $\begin{array}{l}-0.003 \\
(0.155)\end{array}$ & $\begin{array}{l}-0.0007 \\
(0.726)\end{array}$ & $\begin{array}{l}-0.007 * * * \\
(0.001)\end{array}$ & $\begin{array}{l}-0.001 \\
(0.386)\end{array}$ & $\begin{array}{l}-0.014 * * \\
(0.010)\end{array}$ & $\begin{array}{l}-0.002 \\
(0.378)\end{array}$ & $\begin{array}{l}-0.010^{* * *} \\
(0.012)\end{array}$ & $\begin{array}{l}-0.009 * * \\
(0.044)\end{array}$ \\
\hline GDP growth & $\begin{array}{l}-0.002 \\
(0.472)\end{array}$ & $\begin{array}{l}-0.002 \\
(0.275)\end{array}$ & $\begin{array}{l}-0.002 \\
(0.404)\end{array}$ & $\begin{array}{l}-0.003 \\
(0.224)\end{array}$ & $\begin{array}{l}0.018 * * * \\
(0.000)\end{array}$ & $\begin{array}{l}0.014 * * * \\
(0.000)\end{array}$ & $\begin{array}{l}0.020^{* * * *} \\
(0.000)\end{array}$ & $\begin{array}{l}0.017 * * * \\
(0.000)\end{array}$ & $\begin{array}{l}0.021 * * * * \\
(0.000)\end{array}$ & $\begin{array}{l}0.019 * * * \\
(0.001)\end{array}$ & $\begin{array}{l}0.021 * * * * \\
(0.000)\end{array}$ & $\begin{array}{l}0.022 * * * * \\
(0.000)\end{array}$ \\
\hline Inflation & $\begin{array}{l}0.003 \\
(0.549)\end{array}$ & $\begin{array}{l}-0.0006 \\
(0.857)\end{array}$ & $\begin{array}{l}0.001 \\
(0.717)\end{array}$ & $\begin{array}{l}0.0006 \\
(0.899)\end{array}$ & $\begin{array}{l}-0.0001 \\
(0.957)\end{array}$ & $\begin{array}{l}-0.001 \\
(0.630)\end{array}$ & $\begin{array}{l}0.001 \\
(0.758)\end{array}$ & $\begin{array}{l}-0.0002 \\
(0.942)\end{array}$ & $\begin{array}{l}-0.001 \\
(0.864)\end{array}$ & $\begin{array}{l}0.006 \\
(0.371)\end{array}$ & $\begin{array}{l}-0.001 \\
(0.884)\end{array}$ & $\begin{array}{l}-0.001 \\
(0.829)\end{array}$ \\
\hline Foreign investment & $\begin{array}{l}0.002 \\
(0.248)\end{array}$ & $\begin{array}{l}0.002 * * \\
(0.048)\end{array}$ & $\begin{array}{l}0.002 \\
(0.206)\end{array}$ & $\begin{array}{l}0.002 \\
(0.171)\end{array}$ & $\begin{array}{l}-0.002 \\
(0.113)\end{array}$ & $\begin{array}{l}-0.0007 \\
(0.516)\end{array}$ & $\begin{array}{l}-0.001 \\
(0.286)\end{array}$ & $\begin{array}{l}-0.002 * \\
(0.070)\end{array}$ & $\begin{array}{l}0.0008 \\
(0.636)\end{array}$ & $\begin{array}{l}0.001 \\
(0.370)\end{array}$ & $\begin{array}{l}0.002 \\
(0.126)\end{array}$ & $\begin{array}{l}0.0003 \\
(0.871)\end{array}$ \\
\hline Education & $\begin{array}{l}0.006 * * * \\
(0.000)\end{array}$ & $\begin{array}{l}0.003 * * * * \\
(0.001)\end{array}$ & $\begin{array}{l}0.005 * * * * \\
(0.000)\end{array}$ & $\begin{array}{l}0.006 * * * * \\
(0.000)\end{array}$ & $\begin{array}{l}0.005 * * * \\
(0.000)\end{array}$ & $\begin{array}{l}0.003 * * * \\
(0.000)\end{array}$ & $\begin{array}{l}0.005 * * * \\
(0.000)\end{array}$ & $\begin{array}{l}0.004 * * * \\
(0.000)\end{array}$ & $\begin{array}{l}0.012 * * * * \\
(0.000)\end{array}$ & $\begin{array}{l}0.008 * * * \\
(0.000)\end{array}$ & $\begin{array}{l}0.010^{* * * *} \\
(0.001)\end{array}$ & $\begin{array}{l}0.012 * * * \\
(0.000)\end{array}$ \\
\hline Government Expenditure & $\begin{array}{l}0.0006 \\
(0.124)\end{array}$ & $\begin{array}{l}0.001 * * * * \\
(0.000)\end{array}$ & $\begin{array}{l}0.001 * * * * \\
(0.003)\end{array}$ & $\begin{array}{l}0.0005 \\
(0.167)\end{array}$ & $\begin{array}{l}-0.0009 * * \\
(0.037)\end{array}$ & $\begin{array}{l}-0.0002 \\
(0.408)\end{array}$ & $\begin{array}{l}-0.0006 \\
(0.164)\end{array}$ & $\begin{array}{l}-0.0006 * \\
(0.077)\end{array}$ & $\begin{array}{l}0.001 \\
(0.104)\end{array}$ & $\begin{array}{l}0.001 * * * \\
(0.000)\end{array}$ & $\begin{array}{l}0.001 * \\
(0.053)\end{array}$ & $\begin{array}{l}0.001 * \\
(0.086)\end{array}$ \\
\hline $\begin{array}{l}\operatorname{AR}(1) \\
\operatorname{AR}(2) \\
\text { Sargan OIR } \\
\text { Hansen OIR }\end{array}$ & $\begin{array}{l}(\mathbf{0 . 2 3 7}) \\
(0.034) \\
(\mathbf{0 . 7 2 6}) \\
(\mathbf{0 . 3 5 7})\end{array}$ & $\begin{array}{l}(0.315) \\
(0.147) \\
(0.873) \\
(0.536)\end{array}$ & $\begin{array}{l}(\mathbf{0 . 1 8 3}) \\
(0.040) \\
(\mathbf{0 . 8 5 9}) \\
(\mathbf{0 . 2 0 3})\end{array}$ & $\begin{array}{l}(\mathbf{0 . 3 5 5}) \\
(0.047) \\
(\mathbf{0 . 8 0 2}) \\
(\mathbf{0 . 2 5 9})\end{array}$ & $\begin{array}{l}(\mathbf{0 . 2 5 3}) \\
(\mathbf{0 . 3 2 9}) \\
(0.035) \\
(\mathbf{0 . 4 9 5})\end{array}$ & $\begin{array}{l}(\mathbf{0 . 2 5 0}) \\
(0.070) \\
(0.073) \\
(\mathbf{0 . 3 3 4})\end{array}$ & $\begin{array}{l}(\mathbf{0 . 3 4 4 )} \\
(\mathbf{0 . 1 6 9 )} \\
(0.088) \\
(\mathbf{0 . 5 7 3})\end{array}$ & $\begin{array}{l}(\mathbf{0 . 2 3 5}) \\
(\mathbf{0 . 2 8 6}) \\
(0.030) \\
(\mathbf{0 . 4 7 1 )}\end{array}$ & $\begin{array}{l}(0.305) \\
(0.106) \\
(0.538) \\
(0.568)\end{array}$ & $\begin{array}{l}(0.215) \\
(0.101) \\
(0.665) \\
(0.182)\end{array}$ & $\begin{array}{l}(0.210) \\
(0.112) \\
(0.744) \\
(0.499)\end{array}$ & $\begin{array}{l}(0.309) \\
(0.122) \\
(0.525) \\
(0.488)\end{array}$ \\
\hline $\begin{array}{l}\text { DHT for instruments } \\
\text { (a)Instruments in levels }\end{array}$ & & & & & & & & & & & & \\
\hline $\begin{array}{l}\text { H excluding group } \\
\text { Dif(null, H=exogenous) } \\
\text { (b) IV (years, eg(diff)) }\end{array}$ & $\begin{array}{l}(0.720) \\
(0.200)\end{array}$ & $\begin{array}{l}(0.251) \\
(0.699)\end{array}$ & $\begin{array}{l}(0.362) \\
(0.190)\end{array}$ & $\begin{array}{l}(\mathbf{0 . 5 2 3}) \\
(\mathbf{0 . 1 8 5})\end{array}$ & $\begin{array}{l}(0.606) \\
(0.384)\end{array}$ & $\begin{array}{l}(0.475) \\
(0.279)\end{array}$ & $\begin{array}{l}(0.548) \\
(0.508)\end{array}$ & $\begin{array}{l}(\mathbf{0 . 4 9 5}) \\
(\mathbf{0 . 4 2 2})\end{array}$ & $\begin{array}{l}(\mathbf{0 . 7 9 4}) \\
(\mathbf{0 . 3 5 8})\end{array}$ & $\begin{array}{l}(\mathbf{0 . 7 5 6}) \\
(0.072)\end{array}$ & $\begin{array}{l}(0.820) \\
(0.278)\end{array}$ & $\begin{array}{l}(0.825) \\
(0.266)\end{array}$ \\
\hline $\begin{array}{l}\mathrm{H} \text { excluding group } \\
\text { Dif(null, } \mathrm{H}=\text { exogenous) }\end{array}$ & $\begin{array}{l}(0.222) \\
(0.928)\end{array}$ & $\begin{array}{l}(0.572) \\
(0.321)\end{array}$ & $\begin{array}{l}(0.132) \\
(0.732)\end{array}$ & $\begin{array}{l}(0.165) \\
(0.808)\end{array}$ & $\begin{array}{l}(0.500) \\
(0.381)\end{array}$ & $\begin{array}{l}(0.253) \\
(0.655)\end{array}$ & $\begin{array}{l}(0.590) \\
(0.366)\end{array}$ & $\begin{array}{l}(0.423) \\
(0.517)\end{array}$ & $\begin{array}{l}(0.702) \\
(0.178)\end{array}$ & $\begin{array}{l}(\mathbf{0 . 4 2 0}) \\
(0.042)\end{array}$ & $\begin{array}{l}(0.710) \\
(0.104)\end{array}$ & $\begin{array}{l}(0.690) \\
(0.110)\end{array}$ \\
\hline $\begin{array}{l}\text { Fisher } \\
\text { Instruments } \\
\text { Countries } \\
\text { Observations }\end{array}$ & $\begin{array}{l}\mathbf{6 2 0 . 9 6} * * * \\
34 \\
46 \\
131\end{array}$ & $\begin{array}{l}\mathbf{3 2 5 . 8} * * * * \\
34 \\
46 \\
131\end{array}$ & $\begin{array}{l}\mathbf{2 4 7 . 5} * * * \\
34 \\
46 \\
131\end{array}$ & $\begin{array}{l}\mathbf{4 6 2 . 2} * * * * \\
34 \\
46 \\
131\end{array}$ & $\begin{array}{l}\mathbf{4 8 9 . 3 1} * * * \\
34 \\
46 \\
131\end{array}$ & $\begin{array}{l}\mathbf{4 9 7 . 4 0} * * * \\
34 \\
46 \\
131\end{array}$ & $\begin{array}{l}\mathbf{8 1 6 . 2} * * * * \\
34 \\
46 \\
131\end{array}$ & $\begin{array}{l}\mathbf{4 1 3 . 0 6} * * * * \\
34 \\
46 \\
131\end{array}$ & $\begin{array}{l}\mathbf{5 3 3 . 2 7} * * * * \\
34 \\
46 \\
131\end{array}$ & $\begin{array}{l}\mathbf{2 9 7 . 4 8} * * * \\
34 \\
46 \\
131\end{array}$ & $\begin{array}{l}\mathbf{9 8 5 . 9} * * * * \\
34 \\
46 \\
131\end{array}$ & $\begin{array}{l}\mathbf{5 0 8 . 1} * * * * \\
34 \\
46 \\
131\end{array}$ \\
\hline
\end{tabular}

***,***: significance levels of $10 \%, 5 \%$ and $1 \%$ respectively. DHT: Difference in Hansen Test for Exogeneity of Instruments' Subsets. Dif: Difference. OIR: Over-identifying Restrictions (OIR) Test. The significance of bold values is twofold. 1) The significance of estimated coefficients, the Fisher statistics. 2) The failure to reject the null hypotheses of: a) no autocorrelation in the AR(1) and AR(2) tests and; b) the validity of the instruments in the Sargan and Hansen OIR tests. 
Table 4: Institutional Governance and Terrorism

Dependent Variables: Institutional Governance Dynamics

\begin{tabular}{|c|c|c|c|c|c|c|c|c|c|c|c|c|}
\hline \multirow[b]{2}{*}{ Constant } & & & & & & & & & & & & \\
\hline & $\begin{array}{l}-0.226 * * * * \\
(0.005)\end{array}$ & $\begin{array}{l}-0.120 * \\
(0.076)\end{array}$ & $\begin{array}{l}-0.252 * * * \\
(0.003)\end{array}$ & $\begin{array}{l}-0.216 * * * \\
(0.005)\end{array}$ & $\begin{array}{l}-0.160 * \\
(0.094)\end{array}$ & $\begin{array}{l}-0.087 \\
(0.210)\end{array}$ & $\begin{array}{l}-0.133 * \\
(0.073)\end{array}$ & $\begin{array}{l}-0.142 \\
(0.102)\end{array}$ & $\begin{array}{l}-0.385 * * * \\
(0.008)\end{array}$ & $\begin{array}{l}-0.092 \\
(0.372)\end{array}$ & $\begin{array}{l}-0.351^{* *} * \\
(0.010)\end{array}$ & $\begin{array}{l}-0.307 * * \\
(0.033)\end{array}$ \\
\hline $\mathrm{RL}(-1)$ & $\begin{array}{l}0.853 * * * \\
(0.000)\end{array}$ & $\begin{array}{l}0.906 * * * * \\
(0.000)\end{array}$ & $\begin{array}{l}0.850 * * * \\
(0.000)\end{array}$ & $\begin{array}{l}0.851 * * * \\
(0.000)\end{array}$ & -- & -- & -- & -- & -- & -- & --- & --- \\
\hline $\mathrm{CC}(-1)$ & --- & --- & --- & --- & $\begin{array}{l}\mathbf{0 . 8 8 4} * * * \\
(\mathbf{0 . 0 0 0 )}\end{array}$ & $\begin{array}{l}0.891 * * * \\
(0.000)\end{array}$ & $\begin{array}{l}0.861^{* * * * *} \\
(0.000)\end{array}$ & $\begin{array}{l}0.910^{* * * *} \\
(0.000)\end{array}$ & --- & --- & --- & --- \\
\hline Instgov (-1) & --- & --- & --- & --- & --- & --- & --- & --- & $\begin{array}{l}0.864 * * * \\
(0.000)\end{array}$ & $\begin{array}{l}0.866 * * * \\
(0.000)\end{array}$ & $\begin{array}{l}0.797 * * * \\
(0.000)\end{array}$ & $\begin{array}{l}0.867 * * * \\
(0.000)\end{array}$ \\
\hline Domestic Terrorism & $\begin{array}{l}0.004 \\
(0.737)\end{array}$ & --- & --- & --- & $\begin{array}{l}0.038 * \\
(0.069)\end{array}$ & --- & --- & --- & $\begin{array}{l}0.061 \\
(0.131)\end{array}$ & --- & --- & --- \\
\hline Transnational Terrorism & --- & $\begin{array}{l}-0.029 \\
(0.111)\end{array}$ & --- & --- & --- & $\begin{array}{l}-0.042 \\
(0.229)\end{array}$ & --- & --- & --- & $\begin{array}{l}-0.110 \\
(0.148)\end{array}$ & --- & --- \\
\hline Unclear Terrorism & --- & --- & $\begin{array}{l}0.015 \\
(0.716)\end{array}$ & --- & --- & --- & $\begin{array}{l}0.040 \\
(0.427)\end{array}$ & --- & --- & --- & $\begin{array}{l}-0.028 \\
(0.791)\end{array}$ & --- \\
\hline Total Terrorism & --- & --- & -- & $\begin{array}{l}-0.008 \\
(0.562)\end{array}$ & --- & --- & --- & $\begin{array}{l}0.033 \\
(0.142)\end{array}$ & --- & --- & --- & $\begin{array}{l}0.023 \\
(0.620)\end{array}$ \\
\hline Internet & $\begin{array}{l}-0.003 * * \\
(0.031)\end{array}$ & $\begin{array}{l}0.001 \\
(0.161)\end{array}$ & $\begin{array}{l}-0.004 * \\
(0.052)\end{array}$ & $\begin{array}{l}-0.002 \\
(0.114)\end{array}$ & $\begin{array}{l}-0.005 * * \\
(0.023)\end{array}$ & $\begin{array}{l}-0.0005 \\
(0.709)\end{array}$ & $\begin{array}{l}-0.002 \\
(0.282)\end{array}$ & $\begin{array}{l}-0.004 * * \\
(0.044)\end{array}$ & $\begin{array}{l}-0.015 * * * \\
(0.008)\end{array}$ & $\begin{array}{l}0.002 \\
(0.636)\end{array}$ & $\begin{array}{l}-0.005 \\
(0.322)\end{array}$ & $\begin{array}{l}-0.010^{*} \\
(0.079)\end{array}$ \\
\hline GDP growth & $\begin{array}{l}-0.003 \\
(0.279)\end{array}$ & $\begin{array}{l}-0.001 \\
(0.624)\end{array}$ & $\begin{array}{l}-0.003 \\
(0.208)\end{array}$ & $\begin{array}{l}-0.003 \\
(0.173)\end{array}$ & $\begin{array}{l}-0.003 \\
(0.518)\end{array}$ & $\begin{array}{l}-0.005 \\
(0.204)\end{array}$ & $\begin{array}{l}-0.005 \\
(0.356)\end{array}$ & $\begin{array}{l}-0.0005 \\
(0.911)\end{array}$ & $\begin{array}{l}-0.008 \\
(0.261)\end{array}$ & $\begin{array}{l}-0.014 * * \\
(0.030)\end{array}$ & $\begin{array}{l}-0.014^{*} \\
(0.090)\end{array}$ & $\begin{array}{l}-0.008 \\
(0.212)\end{array}$ \\
\hline Inflation & $\begin{array}{l}-0.010 \\
(0.108)\end{array}$ & $\begin{array}{l}-0.001 \\
(0.645)\end{array}$ & $\begin{array}{l}-0.005 \\
(0.255)\end{array}$ & $\begin{array}{l}-0.007 \\
(0.196)\end{array}$ & $\begin{array}{l}-0.013 * * \\
(0.041)\end{array}$ & $\begin{array}{l}-0.014 * * \\
(0.018)\end{array}$ & $\begin{array}{l}-0.017 * * \\
(0.013)\end{array}$ & $\begin{array}{l}-0.014 * * \\
(0.031)\end{array}$ & $\begin{array}{l}-0.018 \\
(0.160)\end{array}$ & $\begin{array}{l}-0.009 \\
(0.315)\end{array}$ & $\begin{array}{l}-0.014 \\
(0.211)\end{array}$ & $\begin{array}{l}-0.010 \\
(0.427)\end{array}$ \\
\hline Foreign investment & $\begin{array}{l}0.002 * * \\
(0.019)\end{array}$ & $\begin{array}{l}0.001 * * \\
(0.026)\end{array}$ & $\begin{array}{l}0.002 * * \\
(0.013)\end{array}$ & $\begin{array}{l}0.002 * * \\
(0.030)\end{array}$ & $\begin{array}{l}0.002 \\
(0.332)\end{array}$ & $\begin{array}{l}0.003 \\
(0.123)\end{array}$ & $\begin{array}{l}0.004^{*} \\
(0.059)\end{array}$ & $\begin{array}{l}0.003 \\
(0.107)\end{array}$ & $\begin{array}{l}0.004 \\
(0.162)\end{array}$ & $\begin{array}{l}0.005^{*} \\
(0.070)\end{array}$ & $\begin{array}{l}0.006 * * \\
(0.028)\end{array}$ & $\begin{array}{l}0.004 \\
(0.169)\end{array}$ \\
\hline Education & $\begin{array}{l}0.004 * * * \\
(0.002)\end{array}$ & $\begin{array}{l}0.0008 \\
(0.437)\end{array}$ & $\begin{array}{l}0.004 * * * \\
(0.001)\end{array}$ & $\begin{array}{l}0.004 * * * * \\
(0.003)\end{array}$ & $\begin{array}{l}0.004 * * \\
(0.019)\end{array}$ & $\begin{array}{l}0.002 * * \\
(0.023)\end{array}$ & $\begin{array}{l}0.003 * * * * \\
(0.004)\end{array}$ & $\begin{array}{l}0.003 * * \\
(0.019)\end{array}$ & $\begin{array}{l}0.012 * * * \\
(0.001)\end{array}$ & $\begin{array}{l}0.002 \\
(0.200)\end{array}$ & $\begin{array}{l}0.009 * * * * \\
(0.004)\end{array}$ & $\begin{array}{l}0.009 * * * \\
(0.009)\end{array}$ \\
\hline Government Expenditure & $\begin{array}{l}0.0009 * * * \\
(0.003)\end{array}$ & $\begin{array}{l}0.001 * * * \\
(0.000)\end{array}$ & $\begin{array}{l}0.0009 * * \\
* \\
(0.004)\end{array}$ & $\begin{array}{l}0.0009 * * \\
* \\
(0.000)\end{array}$ & $\begin{array}{l}0.001 * * * \\
(0.002)\end{array}$ & $\begin{array}{l}0.001 * * * \\
(0.000)\end{array}$ & $\begin{array}{l}0.001 * * \\
(0.012)\end{array}$ & $\begin{array}{l}0.001 * * * \\
(0.003)\end{array}$ & $\begin{array}{l}0.002 * * * \\
(0.001)\end{array}$ & $\begin{array}{l}0.003 * * * \\
(0.000)\end{array}$ & $\begin{array}{l}0.002 * * * \\
(0.006)\end{array}$ & $\begin{array}{l}0.002 * * * * \\
(0.000)\end{array}$ \\
\hline $\begin{array}{l}\operatorname{AR}(1) \\
\operatorname{AR}(2) \\
\text { Sargan OIR } \\
\text { Hansen OIR }\end{array}$ & $\begin{array}{l}(0.242) \\
(0.807) \\
(0.152) \\
(0.252)\end{array}$ & $\begin{array}{l}(0.151) \\
(0.899) \\
(0.193) \\
(0.266)\end{array}$ & $\begin{array}{l}(0.232) \\
(0.753) \\
(0.293) \\
(0.276)\end{array}$ & $\begin{array}{l}(0.224) \\
(0.776) \\
(0.158) \\
(0.228)\end{array}$ & $\begin{array}{l}(0.061) \\
(\mathbf{0 . 7 1 7}) \\
(\mathbf{0 . 9 7 5}) \\
(\mathbf{0 . 2 1 5})\end{array}$ & $\begin{array}{l}(0.079) \\
(\mathbf{0 . 4 4 5}) \\
(\mathbf{0 . 8 5 4}) \\
(\mathbf{0 . 5 9 7})\end{array}$ & $\begin{array}{l}(0.075) \\
(\mathbf{0 . 4 6 3 )} \\
(\mathbf{0 . 9 7 2}) \\
(\mathbf{0 . 2 3 9})\end{array}$ & $\begin{array}{l}(0.062) \\
(\mathbf{0 . 6 2 8}) \\
(\mathbf{0 . 9 5 6 )} \\
(\mathbf{0 . 6 2 8})\end{array}$ & $\begin{array}{l}(0.293) \\
(0.740) \\
(0.705) \\
(0.518)\end{array}$ & $\begin{array}{l}(0.139) \\
(0.631) \\
(0.348) \\
(0.814)\end{array}$ & $\begin{array}{l}(0.278) \\
(0.698) \\
(0.729) \\
(0.493)\end{array}$ & $\begin{array}{l}(0.237) \\
(0.946) \\
(0.595) \\
(0.423)\end{array}$ \\
\hline $\begin{array}{l}\text { DHT for instruments } \\
\text { (a)Instruments in levels }\end{array}$ & & & & & & & & & & & & \\
\hline $\begin{array}{l}\text { H excluding group } \\
\text { Dif(null, H=exogenous) } \\
\text { (b) IV (years, eq(diff)) }\end{array}$ & $\begin{array}{l}(0.444) \\
(0.207)\end{array}$ & $\begin{array}{l}(0.247) \\
(0.344)\end{array}$ & $\begin{array}{l}(0.257) \\
(0.350)\end{array}$ & $\begin{array}{l}(0.277) \\
(0.268)\end{array}$ & $\begin{array}{l}(0.509) \\
(0.149)\end{array}$ & $\begin{array}{l}(0.512) \\
(0.560)\end{array}$ & $\begin{array}{l}(0.601) \\
(0.143)\end{array}$ & $\begin{array}{l}(0.446) \\
(0.184)\end{array}$ & $\begin{array}{l}(0.613) \\
(0.405)\end{array}$ & $\begin{array}{l}(0.529) \\
(0.823)\end{array}$ & $\begin{array}{l}(0.701) \\
(0.332)\end{array}$ & $\begin{array}{l}(0.460) \\
(0.387)\end{array}$ \\
\hline $\begin{array}{l}\text { H excluding group } \\
\text { Dif(null, } H=\text { exogenous) }\end{array}$ & $\begin{array}{l}(0.201) \\
(0.548)\end{array}$ & $\begin{array}{l}(\mathbf{0 . 2 7 1}) \\
(\mathbf{0 . 3 3 6})\end{array}$ & $\begin{array}{l}(0.253) \\
(0.427)\end{array}$ & $\begin{array}{l}(0.200) \\
(0.441)\end{array}$ & $\begin{array}{l}(0.231) \\
(0.288)\end{array}$ & $\begin{array}{l}(0.646) \\
(0.306)\end{array}$ & $\begin{array}{l}(\mathbf{0 . 4 0 0}) \\
(0.094)\end{array}$ & $\begin{array}{l}(0.270) \\
(0.236)\end{array}$ & $\begin{array}{l}(0.402) \\
(0.759)\end{array}$ & $\begin{array}{l}(0.780) \\
(0.577)\end{array}$ & $\begin{array}{l}(0.582) \\
(0.227)\end{array}$ & $\begin{array}{l}(0.335) \\
(0.659)\end{array}$ \\
\hline $\begin{array}{l}\text { Fisher } \\
\text { Instruments } \\
\text { Countries } \\
\text { Observations }\end{array}$ & $\begin{array}{l}\mathbf{6 1 1 . 1 2} * * * * \\
34 \\
46 \\
131\end{array}$ & $\begin{array}{l}\mathbf{4 5 4 . 7} * * * * \\
34 \\
46 \\
131\end{array}$ & $\begin{array}{l}\mathbf{5 0 7 . 0} * * * \\
34 \\
46 \\
131\end{array}$ & $\begin{array}{l}\mathbf{5 8 7 . 0} * * * \\
34 \\
46 \\
131\end{array}$ & $\begin{array}{l}\text { 170.96*** } \\
34 \\
46 \\
131\end{array}$ & $\begin{array}{l}\mathbf{1 5 2 . 7 7} * * * \\
34 \\
46 \\
131\end{array}$ & $\begin{array}{l}\mathbf{2 3 8 . 9} * * * * \\
34 \\
46 \\
131\end{array}$ & $\begin{array}{l}\mathbf{1 6 4 . 1 5} * * * \\
34 \\
46 \\
131\end{array}$ & $\begin{array}{l}\mathbf{2 5 0 . 0 4} * * * \\
34 \\
46 \\
131\end{array}$ & $\begin{array}{l}\mathbf{4 1 5 . 2 1} * * * * \\
34 \\
46 \\
131\end{array}$ & $\begin{array}{l}\mathbf{3 1 5 . 7} * * * \\
34 \\
46 \\
131\end{array}$ & $\begin{array}{l}\mathbf{2 4 6 . 3} * * * * \\
34 \\
46 \\
131\end{array}$ \\
\hline
\end{tabular}

*,**,***: significance levels of $10 \%, 5 \%$ and $1 \%$ respectively. DHT: Difference in Hansen Test for Exogeneity of Instruments' Subsets. Dif: Difference. OIR: Over-identifying Restrictions (OIR) Test. The significance of bold values is twofold. 1) The significance of estimated coefficients, the Fisher statistics. 2) The failure to reject the null hypotheses of: a) no autocorrelation in the AR(1) and AR(2) tests and; b) the validity of the instruments in the Sargan and Hansen OIR tests. 
Table 5: General Governance and Terrorism

\begin{tabular}{|c|c|c|c|c|}
\hline \multirow[b]{2}{*}{ Constant } & \multicolumn{4}{|c|}{ Dependent variable: General Governance (G.Gov) } \\
\hline & $\begin{array}{l}-\mathbf{0 . 6 5 5} * * * \\
(0.001)\end{array}$ & $\begin{array}{l}-\mathbf{- 0 . 2 7 0} * * \\
(\mathbf{0 . 0 2 8})\end{array}$ & $\begin{array}{l}-\mathbf{0 . 6 1 9 * * * *} \\
(0.001)\end{array}$ & $\begin{array}{l}-(0.622 * * * * \\
(0.003)\end{array}$ \\
\hline G.Gov $(-1)$ & $\begin{array}{l}0.930 * * * \\
(0.000)\end{array}$ & $\begin{array}{l}0.918 * * * \\
(0.000)\end{array}$ & $\begin{array}{l}\mathbf{0 . 9 2 0 * * * *} \\
(0.000)\end{array}$ & $\begin{array}{l}0.905 * * * \\
(0.000)\end{array}$ \\
\hline Domestic Terrorism & $\begin{array}{l}-0.004 \\
(0.896)\end{array}$ & --- & -- & --- \\
\hline Transnational Terrorism & --- & $\begin{array}{l}-0.392 * * * * \\
(0.000)\end{array}$ & --- & --- \\
\hline Unclear Terrorism & --- & --- & $\begin{array}{l}-0.072 \\
(0.587)\end{array}$ & --- \\
\hline Total Terrorism & --- & --- & --- & $\begin{array}{l}-0.092 * * \\
(0.024)\end{array}$ \\
\hline Internet & $\begin{array}{l}-0.014 * * \\
(0.029)\end{array}$ & $\begin{array}{l}\mathbf{0 . 0 0 8} * \\
(\mathbf{0 . 0 5 8})\end{array}$ & $\begin{array}{l}-0.009 \\
(0.108)\end{array}$ & $\begin{array}{l}-0.009 \\
(0.181)\end{array}$ \\
\hline GDP growth & $\begin{array}{l}\mathbf{0 . 0 3 0} * * * \\
(0.003)\end{array}$ & $\begin{array}{l}\text { 0.021** } \\
(\mathbf{0 . 0 1 3 )}\end{array}$ & $\begin{array}{l}\mathbf{0 . 0 3 2} * * * \\
(\mathbf{0 . 0 0 3 )}\end{array}$ & $\begin{array}{l}\mathbf{0 . 0 2 7} * * * \\
(0.005)\end{array}$ \\
\hline Inflation & $\begin{array}{l}-0.0004 \\
(0.975)\end{array}$ & $\begin{array}{l}0.014 \\
(0.218)\end{array}$ & $\begin{array}{l}0.008 \\
(0.494)\end{array}$ & $\begin{array}{l}0.010 \\
(0.417)\end{array}$ \\
\hline Foreign investment & $\begin{array}{l}-0.004 \\
(0.291)\end{array}$ & $\begin{array}{l}-0.003 \\
(0.390)\end{array}$ & $\begin{array}{l}-0.002 \\
(0.510)\end{array}$ & $\begin{array}{l}-0.006 * \\
(0.095)\end{array}$ \\
\hline Education & $\begin{array}{l}0.013 * * \\
(0.012)\end{array}$ & $\begin{array}{l}0.0007 \\
(0.795)\end{array}$ & $\begin{array}{l}0.010 * * \\
(0.024)\end{array}$ & $\begin{array}{l}0.012 * * \\
(0.021)\end{array}$ \\
\hline Government Expenditure & $\begin{array}{l}0.002 * * \\
(0.019)\end{array}$ & $\begin{array}{l}0.004 * * * \\
(0.000)\end{array}$ & $\begin{array}{l}0.002 * * \\
(0.012)\end{array}$ & $\begin{array}{l}0.002 * * \\
(0.012)\end{array}$ \\
\hline $\begin{array}{l}\operatorname{AR}(1) \\
\text { AR(2) } \\
\text { Sargan OIR } \\
\text { Hansen OIR }\end{array}$ & $\begin{array}{l}(0.163) \\
(0.574) \\
(0.287) \\
(0.263)\end{array}$ & $\begin{array}{l}(0.037) \\
(\mathbf{0 . 5 1 2}) \\
(\mathbf{0 . 2 5 2}) \\
(\mathbf{0 . 3 2 4})\end{array}$ & $\begin{array}{l}(0.125) \\
(0.461) \\
(0.358) \\
(0.269)\end{array}$ & $\begin{array}{l}(0.154) \\
(0.549) \\
(0.244) \\
(0.214)\end{array}$ \\
\hline $\begin{array}{l}\text { DHT for instruments } \\
\text { (a)Instruments in levels } \\
\text { H excluding group } \\
\text { Dif(null, H=exogenous) } \\
\text { (b) IV (years, eq(diff)) } \\
\text { H excluding group } \\
\text { Dif(null, H=exogenous) }\end{array}$ & $\begin{array}{l}(0.520) \\
(0.189) \\
(0.380) \\
(0.139)\end{array}$ & $\begin{array}{l}(\mathbf{0 . 6 2 6}) \\
(\mathbf{0 . 2 0 6}) \\
(0.559) \\
(0.072)\end{array}$ & $\begin{array}{l}(0.440) \\
(0.227) \\
(0.389) \\
(0.138)\end{array}$ & $\begin{array}{l}(0.407) \\
(0.183) \\
(0.322) \\
(0.128)\end{array}$ \\
\hline $\begin{array}{l}\text { Fisher } \\
\text { Instruments } \\
\text { Countries } \\
\text { Observations }\end{array}$ & $\begin{array}{l}\mathbf{1 3 1 7 . 7 8} * * * \\
34 \\
46 \\
131\end{array}$ & $\begin{array}{l}\mathbf{1 4 9 2 . 5 5 * * *} \\
34 \\
46 \\
131\end{array}$ & $\begin{array}{l}\mathbf{8 9 3 . 9 8} * * * \\
34 \\
46 \\
131\end{array}$ & $\begin{array}{l}791.11 * * * \\
34 \\
46 \\
131\end{array}$ \\
\hline
\end{tabular}

${ }^{*}, * * * * *$ : significance levels of $10 \%, 5 \%$ and $1 \%$ respectively. DHT: Difference in Hansen Test for Exogeneity of Instruments' Subsets. Dif: Difference. OIR: Over-identifying Restrictions (OIR) Test. The significance of bold values is twofold. 1) The significance of estimated coefficients, the Fisher statistics. 2) The failure to reject the null hypotheses of: a) no autocorrelation in the AR(1) and AR(2) tests and; b) the validity of the instruments in the Sargan and Hansen OIR tests.

\subsection{Further Discussion of Results and Policy Implications}

After cross-examining Tables 2-5, two consistent findings are worth elucidating. On the one hand, terrorism consistently decreases political governance and its constituent parts. On the other, compared to domestic terrorism, transnational terrorism more negatively and significantly affect political, economic and general governances.

The overwhelming deleterious effect of political governance which confirms the tested hypothesis is traceable to the definition of terrorism employed in the general literature. For example, according to Enders and Todd (2006), terrorism can be understood as threatened use of force by sub-national actors for the goal of employing intimidation to secure political 
goals. The conception, definition and measurement of terrorism are more skewed towards the political dimension of governance. Within this framework, terrorism is designed to either influence political governance positively or negatively. The study has found this impact to be negative. In other words, terrorism reduces the fair and free election and replacement of political leaders. Accordingly, mechanisms of rigging elections may be more apparent in hostile environments. Moreover, some liberties including freedom of expression, association with certain political parties and a free media may be curbed with 'state of emergency laws' during elections when they are characterized by violence and unrests. Ultimately, an unsecured environment owing to terrorism does not offer all elements of a political class the opportunity of organizing civil campaigns properly as it would be the case in an atmosphere without terrorism threats. Moreover, terrorism may provide the incumbent government with the leverage of using the heightened risk of violence with associated national unrest in maintaining their grip on power. This narrative is consistent with Park and Bali (2016) on the relationship between terrorism and political survival.

The higher magnitude of transnational terrorism compared with domestic terrorism could also be explained by the fact that the relationship between terrorism and political survival is more apparent with transnational terrorism (see Park \& Bali, 2016). Beyond citizens rallying around elected leaders in threatening times; transnational terrorism in undermining 'incumbent target governments' also damages society's general well-being. This dimension of welfare is more related to deteriorating economic governance than political governance because the definition of economic governance is more aligned with living standard. This insight also doubles as an explanation as to why the negative magnitude of transnational terrorism is consistently significant in economic governance.

As a policy implication, terrorism more negatively affects the election and replacement of political leaders (political governance) compared with the formulation and implication of policies that deliver public commodities (economic governance). Conversely, it does not significantly influence the respect by the state and citizens of institutions that govern interactions between them (institutional governance).

The comparatively high relevance of terrorism on political governance is supported by the evidence in the literature which for the most part has established how terror events are likely to affect political outcomes (see Berrebi \& Klor 2006; Siqueira \& Sandler 2007). Most notably that terrorism: determines voters' views and the constitution of governments (Jacobson, 2003; Langer \& Cohen, 2005) and influences the survival and effectiveness of incumbent target governments (Indridason et al., 2008; Williams, 2012). 


\section{Conclusion and further research directions}

This study has investigated how terrorism affects governance indicators in 53 African countries for the period 1998-2012. Four terrorism indicators are used. They are: domestic, transnational, unclear and total terrorism. Four composite governance indicators with six unbundled components are also employed. They comprised (1) political governance (consisting of (i) political stability and (ii) voice and accountability), (2) economic governance (encompassing (iii) government effectiveness and (iv) regulation quality); (3) institutional governance (involving (v) corruption-control and (vi) the rule of law) and (4) general governance. The empirical evidence is based on the Generalised Method of Moments. The following findings are established. First, all terrorism dynamics significantly negatively affect political governance and its unbundled constituents. Second, a weak negative relationship is evident with regards to economic governance and its separate parts. Third, no sign of a connection is established with respect to institutional governance and its individual components. Compared to domestic terrorism, transnational terrorism more negatively and significantly affects political, economic and general governances.

Further studies can improve the extant literature by assessing the cost and effectiveness of the different policy tools by which the negative effect of terrorism on political governance can be reduced. Potential policy initiatives could include, inter alia: greater regional integration, military expenditure and inclusive human development. 


\section{Appendices}

Appendix 1: Definitions of Variables

\begin{tabular}{|c|c|c|c|}
\hline Variables & Signs & Variable Definitions (Measurement) & Sources \\
\hline Political Stability & PS & $\begin{array}{l}\text { "Political stability/no violence (estimate): measured as the } \\
\text { perceptions of the likelihood that the government will be } \\
\text { destabilized or overthrown by unconstitutional and violent } \\
\text { means, including domestic violence and terrorism" }\end{array}$ & World Bank (WDI) \\
\hline $\begin{array}{l}\text { Voice \& } \\
\text { Accountability }\end{array}$ & VA & $\begin{array}{l}\text { "Voice and accountability (estimate) measures the extent to } \\
\text { which a country's citizens are able to participate in selecting } \\
\text { their government and to enjoy freedom of expression, } \\
\text { freedom of association and a free media". }\end{array}$ & World Bank (WDI) \\
\hline $\begin{array}{l}\text { Political } \\
\text { Governance }\end{array}$ & Polgov & $\begin{array}{l}\text { First Principal Component of Political Stability and Voice \& } \\
\text { Accountability. The process by which those in authority are } \\
\text { selected and replaced. }\end{array}$ & PCA \\
\hline $\begin{array}{l}\text { Government } \\
\text { Effectiveness }\end{array}$ & GE & $\begin{array}{l}\text { "Government effectiveness (estimate): measures the quality } \\
\text { of public services, the quality and degree of independence } \\
\text { from political pressures of the civil service, the quality of } \\
\text { policy formulation and implementation, and the credibility of } \\
\text { governments' commitments to such policies". }\end{array}$ & World Bank (WDI) \\
\hline $\begin{array}{l}\text { Regulation } \\
\text { Quality }\end{array}$ & RQ & $\begin{array}{l}\text { "Regulation quality (estimate): measured as the ability of the } \\
\text { government to formulate and implement sound policies and } \\
\text { regulations that permit and promote private sector } \\
\text { development". }\end{array}$ & World Bank (WDI) \\
\hline $\begin{array}{l}\text { Economic } \\
\text { Governance }\end{array}$ & Ecogov & $\begin{array}{l}\text { "First Principal Component of Government Effectiveness and } \\
\text { Regulation Quality. The capacity of government to formulate } \\
\text { \& implement policies, and to deliver services". }\end{array}$ & PCA \\
\hline Rule of Law & RL & $\begin{array}{l}\text { "Rule of law (estimate): captures perceptions of the extent to } \\
\text { which agents have confidence in and abide by the rules of } \\
\text { society and in particular the quality of contract enforcement, } \\
\text { property rights, the police, the courts, as well as the likelihood } \\
\text { of crime and violence". }\end{array}$ & World Bank (WDI) \\
\hline $\begin{array}{l}\text { Corruption- } \\
\text { Control }\end{array}$ & $\mathrm{CC}$ & $\begin{array}{l}\text { "Control of corruption (estimate): captures perceptions of the } \\
\text { extent to which public power is exercised for private gain, } \\
\text { including both petty and grand forms of corruption, as well as } \\
\text { "capture' of the state by elites and private interests". }\end{array}$ & World Bank (WDI) \\
\hline $\begin{array}{l}\text { Institutional } \\
\text { Governance }\end{array}$ & Instgov & $\begin{array}{l}\text { First Principal Component of Rule of Law and Corruption- } \\
\text { Control. The respect for citizens and the state of institutions } \\
\text { that govern the interactions among them }\end{array}$ & PCA \\
\hline $\begin{array}{l}\text { General } \\
\text { Governance }\end{array}$ & G.gov & $\begin{array}{l}\text { First Principal Component of Political, Economic and } \\
\text { Institutional Governances }\end{array}$ & PCA \\
\hline $\begin{array}{l}\text { Domestic } \\
\text { terrorism }\end{array}$ & Domter & Number of Domestic terrorism incidents (in Ln) & \\
\hline $\begin{array}{l}\text { Transnational } \\
\text { terrorism }\end{array}$ & Tranter & Number of Transnational terrorism incidents (in Ln) & $\begin{array}{l}\text { Ender et al. (2011) } \\
\text { and }\end{array}$ \\
\hline Uuclear terrorism & Unclter & $\begin{array}{l}\text { Number of terrorism incidents whose category is unclear (in } \\
\text { Ln) }\end{array}$ & $(2012)$ \\
\hline Total terrorism & Totter & Total number of terrorism incidents (in Ln) & \\
\hline Internet & Internet & Internet penetration (per 100 people) & World Bank (WDI) \\
\hline Growth & GDPg & Gross Domestic Product (GDP) growth rates (annual \%) & World Bank (WDI) \\
\hline Inflation & Inflation & Consumer Price Index (annual \%) & World Bank (WDI) \\
\hline $\begin{array}{l}\text { Foreign } \\
\text { investment }\end{array}$ & FDI & Foreign direct investment net inflows (\% of GDP) & World Bank (WDI) \\
\hline
\end{tabular}


Education $\quad$ Educ Secondary school enrolment (\% of Gross)

World Bank (WDI)

Government

G.Exp. Government's Final Consumption Expenditure (\% of GDP)

World Bank (WDI)

Expenditure

WDI: World Bank Development Indicators. PCA: Principal Component Analysis. Ln: Natural logarithm.

\section{Appendix 2: Summary statistics}

\begin{tabular}{|c|c|c|c|c|c|}
\hline & Mean & SD & Minimum & Maximum & Observations \\
\hline Political Stability & -0.551 & 0.929 & -3.297 & 1.087 & 265 \\
\hline Voice \& Accountability & -0.679 & 0.723 & -2.155 & 1.009 & 265 \\
\hline Political Governance & 0.0008 & 1.268 & -3.304 & 2.671 & 265 \\
\hline Government Effectiveness & -0.723 & 0.620 & -2.354 & 0.823 & 265 \\
\hline Regulation Quality & -0.695 & 0.638 & -2.630 & 0.906 & 265 \\
\hline Economic Governance & 0.009 & 1.354 & -3.951 & 3.511 & 265 \\
\hline Rule of Law & -0.706 & 0.660 & -2.595 & 1.032 & 265 \\
\hline Control of Corruption & -0.602 & 0.577 & -1.848 & 0.971 & 265 \\
\hline Institutional Governance & 0.003 & 1.349 & -3.490 & 3.316 & 265 \\
\hline General Governance & 0.008 & 2.170 & -6.208 & 5.242 & 265 \\
\hline Domestic terrorism & 0.401 & 0.805 & 0.000 & 4.781 & 265 \\
\hline Transnational terrorism & 0.203 & 0.451 & 0.000 & 2.802 & 265 \\
\hline Unclear terrorism & 0.060 & 0.193 & 0.000 & 1.566 & 265 \\
\hline Total terrorism & 0.500 & 0.885 & 0.000 & 4.895 & 265 \\
\hline Internet penetration & 4.766 & 8.022 & 0.002 & 51.174 & 264 \\
\hline GDP growth & 4.706 & 4.230 & -8.149 & 32.265 & 259 \\
\hline Inflation & 10.012 & 25.435 & -6.934 & 275.983 & 242 \\
\hline Foreign direct investment & 5.125 & 7.175 & -4.265 & 52.398 & 259 \\
\hline Education (secondary) & 42.416 & 25.022 & 5.608 & 111.454 & 201 \\
\hline Government Expenditure & 8.715 & 22.623 & -62.668 & 206.7 & 206 \\
\hline
\end{tabular}




\section{Appendix 3: Correlation matrix}

\begin{tabular}{|c|c|c|c|c|c|c|c|c|c|c|c|c|c|c|c|c|c|c|c|c|}
\hline \multicolumn{3}{|c|}{ Political governance } & \multicolumn{3}{|c|}{ Economic governance } & \multicolumn{3}{|c|}{ Institutional governance } & \multirow[b]{2}{*}{ G.gov } & \multicolumn{5}{|c|}{ Control variables } & \multicolumn{2}{|c|}{ | } & \multicolumn{2}{|c|}{ Terrorism variables } & \multirow[b]{2}{*}{ Totter } & \multirow[b]{3}{*}{ PS } \\
\hline PS & VA & Polgov & $\mathrm{GE}$ & $\mathrm{RQ}$ & Ecogov & $\mathrm{CC}$ & RL & Instgov & & Internet & FDI & GDPg & Inflation & Educ & G.Exp. & Domter & Tranter & Unclter & & \\
\hline \multirow[t]{20}{*}{1.000} & 0.658 & 0.906 & 0.643 & 0.608 & 0.644 & 0.771 & 0.758 & 0.755 & 0.805 & 0.084 & 0.033 & -0.074 & -0.234 & 0.368 & -0.188 & -0.605 & -0.584 & -0.453 & -0.652 & \\
\hline & 1.000 & 0.914 & 0.719 & 0.730 & 0.745 & 0.715 & 0.773 & 0.765 & 0.849 & 0.187 & -0.092 & -0.184 & -0.049 & 0.390 & -0.126 & -0.263 & -0.276 & -0.160 & -0.287 & VA \\
\hline & & 1.000 & 0.749 & 0.736 & 0.764 & 0.783 & 0.841 & 0.835 & 0.909 & 0.150 & -0.033 & -0.143 & -0.153 & 0.416 & -0.172 & -0.473 & -0.469 & -0.334 & -0.512 & Polgov \\
\hline & & & 1.000 & 0.890 & 0.975 & 0.872 & 0.892 & 0.907 & 0.935 & 0.303 & -0.178 & -0.184 & -0.112 & 0.570 & -0.143 & -0.225 & -0.271 & -0.175 & -0.256 & GE \\
\hline & & & & 1.000 & 0.969 & 0.799 & 0.852 & 0.849 & 0.906 & 0.285 & -0.226 & -0.263 & -0.130 & 0.481 & -0.218 & -0.186 & -0.246 & -0.125 & -0.216 & $\mathrm{RQ}$ \\
\hline & & & & & 1.000 & 0.862 & 0.898 & 0.905 & 0.948 & 0.303 & -0.206 & -0.227 & -0.124 & 0.543 & -0.184 & -0.212 & -0.267 & -0.156 & -0.244 & Ecogov \\
\hline & & & & & & 1.000 & 0.888 & 0.970 & 0.960 & 0.224 & -0.099 & -0.269 & -0.166 & 0.523 & -0.172 & -0.294 & -0.335 & -0.278 & -0.336 & $\mathrm{CC}$ \\
\hline & & & & & & & 1.000 & 0.973 & 0.929 & 0.302 & -0.129 & -0.241 & -0.161 & 0.583 & -0.194 & -0.304 & -0.308 & -0.229 & -0.335 & $\mathrm{RL}$ \\
\hline & & & & & & & & 1.000 & 0.972 & 0.270 & -0.117 & -0.263 & -0.169 & 0.568 & -0.188 & -0.307 & -0.331 & -0.262 & -0.345 & Instgov \\
\hline & & & & & & & & & 1.000 & 0.261 & -0.130 & -0.024 & -0.220 & 0.545 & -0.192 & -0.341 & -0.369 & -0.262 & -0.379 & G.gov \\
\hline & & & & & & & & & & 1.000 & -0.103 & -0.023 & -0.062 & 0.535 & -0.021 & 0.146 & 0.164 & 0.187 & 0.145 & Internet \\
\hline & & & & & & & & & & & 1.000 & 0.482 & 0.105 & -0.066 & 0.106 & -0.133 & -0.082 & -0.107 & -0.135 & FDI \\
\hline & & & & & & & & & & & & 1.000 & 0.124 & -0.220 & 0.249 & -0.006 & 0.007 & 0.041 & -0.007 & GDPg \\
\hline & & & & & & & & & & & & & 1.000 & -0.003 & 0.195 & 0.181 & 0.247 & 0.202 & 0.196 & Inflation \\
\hline & & & & & & & & & & & & & & 1.000 & -0.061 & 0.036 & -0.071 & 0.012 & -0.0006 & Educ \\
\hline & & & & & & & & & & & & & & & 1.000 & 0.095 & 0.221 & -0.164 & 0.135 & G.Exp. \\
\hline & & & & & & & & & & & & & & & & 1.000 & 0.699 & 0.785 & 0.978 & Domter \\
\hline & & & & & & & & & & & & & & & & & 1.000 & 0.707 & 0.803 & Tranter \\
\hline & & & & & & & & & & & & & & & & & & 1.000 & 0.810 & Unclter \\
\hline & & & & & & & & & & & & & & & & & & & 1.000 & Totter \\
\hline
\end{tabular}

PS: Political Stability/Non violence. VA: Voice \& Accountability. Polgov: Political Governance. GE: Government Effectiveness. RQ: Regulation Quality. Ecogov: Economic Governance. CC: Corruption-Control. RL: Growth. G.Exp: Government Expenditure. Domter: Domestic Terrorism. Tranter: Transnational Terrorism. Unclter: Unclear Terrorism. Totter: Total Terrorism. 


\begin{tabular}{|c|c|c|c|c|c|c|c|c|c|c|}
\hline & PS & VA & Polgov & GE & RQ & Ecogov & $\mathrm{CC}$ & RL & Instgov & G.gov \\
\hline PS(-1) & 0.925 & & & & & & & & & \\
\hline VA(-1) & & 0.953 & & & & & & & & \\
\hline Polgov(-1) & & & 0.955 & & & & & & & \\
\hline $\mathrm{GE}(-1)$ & & & & 0.965 & & & & & & \\
\hline $\mathrm{RQ}(-1)$ & & & & & 0.966 & & & & & \\
\hline Ecogov(-1) & & & & & & 0.966 & & & & \\
\hline $\mathrm{CC}(-1)$ & & & & & & & 0.936 & & & \\
\hline RL(-1) & & & & & & & & 0.966 & & \\
\hline $\operatorname{Instgov}(-1)$ & & & & & & & & & 0.963 & \\
\hline G.gov(-1) & & & & & & & & & & 0.971 \\
\hline
\end{tabular}

PS: Politcal Stability. PS(-1): lagged value of Political Stability. VA: Voice \& Accountability. Polgov: Political Governance. GE: Government Effectiveness. RQ: Regulation Quality. Ecogov: Economic Governance. CC: Corruption-Control. RL: Rule of Law. Instgov: Institutional Governance. G.Gov: General Governance.

\section{References}

Alfa-Wali, M., Sritharan, K., Mehes, M., Abdullah, F., \& Rasheed, S., (2015). "Terrorismrelated trauma in Africa, an increasing problem", Journal of Epidemiology and Global Health, 5(2), pp. 201-203.

Andrés, A. R., Asongu, S. A., \& Amavilah, V. H. S., (2015). "The Impact of Formal Institutions on Knowledge Economy", Journal of the Knowledge Economy, 6(4), pp. 10341062 .

Anyanwu, J., \& Erhijakpor, A., (2014). "Does Oil Wealth Affect Democracy in Africa?", African Development Review, 26 (1), pp. 15-37.

Arellano, M., \& Bond, S., (1991). "Some tests of specification for panel data: Monte Carlo evidence and an application to employment equations". The Review of Economic Studies, 58(2), pp. 277-297.

Arellano, M., \& Bover, O., (1995). "Another look at the instrumental variable estimation of error-components models", Journal of Econometrics, 68(1), pp. 29-52.

Argomaniz, J., (2015). "European Union responses to terrorist use of the Internet", Cooperation and Conflict, 50 (2), pp. 250-268.

Asongu, S. A., (2012). "Government quality determinants of stock market performance in African countries", Journal of African Business, 13(3), pp. 183-199.

Asongu, S. A., (2015). “On Taxation, Political Accountability and Foreign Aid: Empirics to a Celebrated Literature", South African Journal of Economics, 83(2), pp. 180-198.

Asongu, S. A., (2016). "Determinants of Growth in Fast Developing Countries: Evidence from Bundling and Unbundling Institutions”, Politics \& Policy, 44(1), pp. 97-134.

Asongu, S. A., \& Nwachukwu, J. C., (2016a). "The Role of Lifelong Learning in Political Stability and Non-violence: Evidence from Africa", Journal of Economic Studies, 43(1), pp. 141-164. 
Asongu, S. A., \& Nwachukwu, J. C., (2016b). "Revolution empirics: predicting the Arab Spring”, Empirical Economics, 51(2), pp. 439-482.

Asongu, S. A., \& Nwachukwu, J. C., (2016c). "The Mobile Phone in the Diffusion of Knowledge for Institutional Quality in Sub Saharan Africa", World Development, 86 (October), pp. 133-147.

Asongu, S. A, \& Nwachukwu, J. C., (2016d). "Foreign aid and governance in Africa", International Review of Applied Economics, 30(1), pp. 69-88.

Asongu. S. A., \& Nwachukwu, J. C., (2017). "Fighting Terrorism: Empirics on Policy Harmonization", German Economic Review: DOI: 10.1111/geer.12126.

Asongu, S. A., \& De Moor, L., (2017). "Financial globalisation dynamic thresholds for financial development: evidence from Africa", The European Journal of Development Research, 29(1), pp. 192-212.

Baltagi, B. H., (2008). "Forecasting with panel data", Journal of Forecasting, 27(2), pp. 153173.

Bandyopadhyay, S., Sandler, T., \& Younas, J., (2014). "Foreign direct investment, aid, and terrorism", Oxford Economic Papers, 66(1), pp. 25-50.

Beck, T., Demirgüç-Kunt, A., \& Levine, R., (2003), "Law and finance: why does legal origin matter?", Journal of Comparative Economics, 31(4), pp. 653-675.

Berrebi, C., \& Klor, E., (2006). "On Terrorism and Electoral Outcomes”. Journal of Conflict Resolution, 50(6), pp. 899-925.

Blundell, R., \& Bond, S., (1998). "Initial conditions and moment restrictions in dynamic panel data models", Journal of Econometrics, 87(1), pp. 115-143.

Bond, S., Hoeffler, A., \& Tample, J., (2001). "GMM Estimation of Empirical Growth Models", University of Oxford.

Boulianne, S., (2009). "Does Internet Use Affect Engagement? A Meta-Analysis of Research”, Political Communication, 26(2), pp. 193-211.

Cheung, H.Y. \& Chan, A.W.H., (2008. "Corruption across countries; impacts form education and cultural dimensions”, The Social Science Journal, 45(2), pp. 223-239.

Choi, S-W., (2010). "Fighting Terrorism through the Rule of Law?", The Journal of Conflict Resolution, 54(6), pp. 940-966.

Choi, S-W., \& Salehyan , I., (2013). "No Good Deed Goes Unpunished: Refugees, Humanitarian Aid, and Terrorism", Conflict Management and Peace Sciences, 30(1), pp. 5375.

Clavarino, T., (2014). “Africa, the new outpost of terrorism”, RT op-edge. 
Boyce, J. K. \& O'Donnell, M., (eds.) (2007), Peace and the Public Purse: Economic Policies for Postwar Statebuilding, Lynne Rienner Publishers, Boulder CO.

Boyce, J.K. \& Forman, S., (2010), "Financing Peace: International and National Resources for Postconflict Countries and Fragile States", Background Paper for the World Development Report 2011.

Dewan, S., \& Ramaprasad, J., (2014). "Social media, traditional media and music sales", MIS Quarterly, 38(1), pp. 101-128.

Diamond, L., (2010). “Liberation Technology”, Journal of Democracy, 21(3), pp. 69-83.

Dixit, A., (2009). "Governance Institutions and Economic Activity", American Economic Review, 99(1), pp. 5-24.

Efobi, U., \& Asongu, S. A., (2016). "Terrorism and capital flight from Africa", International Economics, 148(December), pp. 192-212.

Efobi, U., Asongu, S., \& Beecroft, I., (2015). "Foreign Direct Investment, Aid and Terrorism: Empirical Insight Conditioned on Corruption Control", African Governance and Development Institute Working Paper No. 15/007, Yaoundé.

Enders, W., \& Sandler T., (2006). The Political Economy of Terrorism. New York:

Cambridge University Press.

Enders W, Sandler T \& Gaibulloev K., (2011). "Domestic versus transnational terrorism: Data, decomposition, and dynamics”. Journal of Peace Research, 48(3), pp. 319-337.

Eubank, W. L., \& Weinberg, L., (1994). “Does Democracy Encourage Terrorism?” Terrorism and Political Violence, 6(4), pp.417-43.

Eubank, W. L., \& Weinberg, L. B., (2001). "Terrorism and democracy: Perpetrators and victims". Terrorism and Political Violence, 13(1), pp. 155-164.

Eyerman, J., (1998). "Terrorism and Democratic States: Soft Targets or Accessible Systems." International Interactions, 24(2), pp.151-170.

Fazel, A., (2013). "The growing terrorism threat in Africa", Mail \& Guardian, http://mg.co.za/article/2013-12-17-the-growing-terrorism-threat-in-africa 20/01/2016)

(Accessed:

Findley, M. G., \& Young, J. K., (2011). "Terrorism, Democracy, and Credible Commitments.” International Studies Quarterly 55(2), pp.357-578.

Fonchingong, C. C., (2014). "Firming Up Institutional Policy for Deprived Elderly in Cameroon", Politics \& Policy, 42(6), pp. 948-980. 
Foster, P., (2014). "Jihadists from around the world flock to fight with Isil; UN", The Telegraph.

http://www.telegraph.co.uk/news/worldnews/islamic-state/11200701/Jihadists-from-aroundthe-world-flock-to-fight-with-Isil-UN.html (Accessed: 01/12/2015).

Fosu, A. K., (2013), "Growth of African Economies: Productivity, Policy Syndromes and the Importance of Institutions" Journal of African Economies, 22(4), pp. 523-551.

Fosu, A. K., (2015). Growth and Institutions in African Development, First edited by Augustin K. Fosu, , Routledge Studies in Development Economics: New York.

Fukuyama, F., (2013). “What is Governance?”, Governance, 26(3), pp. 347-368.

Gailbulloev, K., Sandler, T., \& Santifort, C., (2012). "Assessing the Evolving Threat of Terrorism", Global Policy, 3(2), pp. 135-144.

Gani, A., (2011). "Governance and Growth in Developing Countries", Journal of Economic Issues, 45(1), pp. 19-40.

Gause, F G. III., (2005). “Can democracy stop terrorism?” Foreign Affairs, 84(5), pp. 62-76.

Grossman, G., Humphreys, M., and Sacramone-Lutz, G., (2014). "“I wld like u WMP to extend electricity 2 our village": On Information Technology and Interest Articulation", American Political Science Review, 108(3), pp. 688-705.

Hoffman, A. M., Shelton, C., \& Cleven, E., (2013). "Press Freedom, Publicity, and the CrossNational Incidence of Transnational Terrorism", Political Research Quarterly, 66 (4), pp. 896-909.

Indridason, I. H., (2008). "Does Terrorism Influence Domestic Politics? Coalition Formation and Terrorist Incidents", Journal of Peace Research, 45(2), pp. 241-259.

Jacobson, G. C., (2003). "Terror, Terrain, and Turnout: Explaining the 2002 Midterm Elections". Political Science Quarterly, 118 (1), pp. 1-22.

Jolliffe, I. T. (2002) Principal Component Analysis (2nd Ed.) New York: Springer.

Kaiser, H. F. (1974) “An index of factorial simplicity” Psychometrika 39(1), pp. 3-36.

Kaufmann, D., Kraay, A., \& Mastruzzi, M., (2007a). "Growth and Governance: A Reply", Journal of Politics, 69(2), pp. 555-562.

Kaufmann, D., Kraay, A., \& Mastruzzi, M., (2007b). "Growth and Governance: A Rejoinder", Journal of Politics, 69(2), pp. 570-572.

Kaufmann, D., Kraay, A \& Mastruzzi, M., (2010). "The worldwide governance indicators: Methodology and analytical Issues". World Bank Policy Research Working Paper No 5430, Washington.

Kibris, A., (2010). “Terrorism, Elections and Ethnicity”. Working Paper, Sabanci University 
Kurtz, M., \& Schrank, A., (2007a). "Growth and Governance: Models, Measures, and Mechanisms", Journal of Politics, 69(2), pp. 538-554.

Kurtz, M., \& Schrank, A., (2007b). "Growth and Governance: A Defense", Journal of Politics, 69(2), pp. 563-569.

Lai, B., (2007). “'Draining the Swamp': An Empirical Examination of the Production of International Terrorism, 1968-1998." Conflict Management and Peace Science, 24(4), pp. 297-310.

Lalountas, D.A., Manolas, G.A., \& Vavouras, I. S., (2011), "Corruption, globalization and development: how are these three phenomena related?", Journal of Policy Modeling, 33(4), pp. 636-648.

Langer, G., \& Cohen, J., (2005). "Voters and Values in the 2004 Election", Public Opinion Quarterly, 69 (5), pp. 744-759.

Laver, M., \& Shepsle, K. A., (1998). "Events, Equilibria, and Government Survival". American Journal of Political Science, 42(1), pp. 28-54

Lederman, D., Loayza, N.V., \& Soares, R.R. (2005), “Accountability and corruption: political institutions matter”, Economics \& Politics, 7(1), pp. 1-35.

Lee, C-Y., (2013). "Democracy, civil liberties and hostage-taking terrorism", Journal of Peace Research, 50(2), pp. 235-248.

Li, Q., (2005). "Does Democracy Promote or Reduce Transnational Terrorist Incidents?" Journal of Conflict Resolution 49(2), pp.278-297.

Love, I., \& Zicchino, L., (2006). "Financial Development and Dynamic Investment Behaviour: Evidence from Panel VAR" .The Quarterly Review of Economics and Finance, 46(2), pp. 190-210.

Mo Ibrahim Foundation (2015). "Governance progress in Africa stalling, reports Mo Ibrahim Foundation", The Mo Ibrahim Foundation, http://static.moibrahimfoundation.org/u/2015/10/02185642/2015-press-release.pdf (Accessed: 05/12/2016).

Park, J., and Bali, V., (2016). "International Terrorism and the Political Survival of Leaders", Journal of Conflict Resolution, DOI: 10.1177/0022002715613139.

Piazza, J., (2007). "Draining the Swamp: Democracy Promotion, State Failure, and Terrorism in 19 Middle Eastern States." Studies in Conflict and Terrorism, 30(6), pp. 521-539.

Piazza, J., (2008a). "Incubators of Terror: Do Failed and Failing States Promote Transnational Terrorism?” International Studies Quarterly, 52(3), pp.468-488.

Piazza, J., (2008b). "Do democracy and free markets protect us from terrorism?" International Politics, 45(1), pp. 72-91. 
Roodman, D., (2009a). "A Note on the Theme of Too Many Instruments", Oxford Bulletin of Economics and Statistics, 71(1), pp. 135-158.

Roodman, D., (2009b). "How to do xtabond2: An introduction to difference and system GMM in Stata", Stata Journal, 9(1), pp. 86-136.

Ross, J. I., (1993). "Structural causes of oppositional political terrorism: Towards a causal model". Journal of Peace Research, 30(3), pp. 317-329.

Savun, B., \& Phillips, B. J., (2009). "Democracy, foreign policy, and terrorism”. Journal of Conflict Resolution, 53(6), pp. 878-904.

Schmid, A. P., (1992). “Terrorism and Democracy." Terrorism and Political Violence, 4(4), pp.14-25.

Siqueira, K., \& Sandler, T., (2007). “Terrorist Backlash, Terrorism Mitigation, and Policy Delegation”. Journal of Public Economics, 91 (9), pp. 1800-1815.

Snow, B. C., (2009). "Mobile Phone Diffusion and Corruption in Africa", Political Communication, 26(3), pp.333-353.

Straus, S., (2012). "Wars do end. Changing Patterns of Political Violence in Sub-Saharan Africa", African Affairs, 111(443), pp. 179-201.

Tabor, J. O., (2016). “Terrorism or clamor for resource control: An analysis of Nigeria's Niger Delta militants", Journal of Terrorism Research, 7(3), pp. 23-34.

Tchamyou, S. V., (2016). "The role of knowledge economy in African business", Journal of the Knowledge Economy, DOI: DOI: 10.1007/s13132-016-0417-1.

Tusalem, R. F., (2015), "State Regulation of Religion and the Quality of Governance", Politics \& Policy, 43(1), pp. 94-141.

Weinberg, L. B., \& Eubank, W. L., (1998). “Terrorism and democracy: What recent events disclose?” Terrorism and Political Violence, 10(1), pp. 108-118.

Williams, L. K., (2012). “The Political Consequences of Terrorism: Terror Events, Casualties, and Government Duration”, International Studies Perspectives, (2012), 1-19.

Windsor, J. L., (2003). "Promoting democratization can combat terrorism". Washington Quarterly, 26(3), pp. 43-58.

Yerrabati, S., \& Hawkes, D., (2015). "Economic Governance and Economic Growth in South and East Asia \& Pacific Region: Evidence from Systematic Literature Reviews and Metaanalysis". Advances in Economics and Business, 3(1), pp. 1 - 21. 